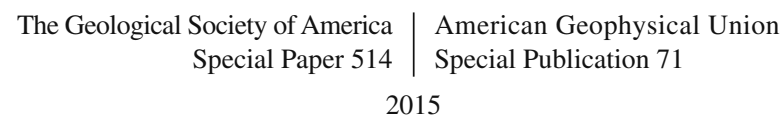

\title{
Generation of low-silica alkaline lavas: Petrological constraints, models, and thermal implications
}

\author{
Sébastien Pilet* \\ Institute of Earth Sciences, Faculty of Geosciences and Environment, University of Lausanne, CH-1015 Lausanne, Switzerland
}

\begin{abstract}
Various hypotheses for the origin of alkaline sodic mafic magmas have been proposed. This diversity of models is mainly related to the various constraints used to develop them. The goal of this paper is to test these different models using petrological and geochemical constraints in an attempt to understand why alkaline sodic rocks are so similar even while their environment of formation varies from oceanic to continental rift. Incompatible trace-element contents of alkaline basalts from ocean islands and continents show that the sources of these rocks are more enriched than primitive mantle. A fundamental question then is how the sources of alkaline rocks acquire these trace-element enrichments.

Recycled oceanic crust, with or without sediment, is often invoked as a source component of alkaline magmas to account for their trace-element and isotopic characteristics. However, the fact that melting of oceanic crust produces silica-rich liquids seems to exclude the direct melting of eclogite derived from mid-ocean-ridge basalt to produce alkaline lavas. Recycling oceanic crust in the source of alkaline magma requires either (1) that the mantle "digests" this component producing metasomatized $\mathrm{CO}_{2}$-rich peridotitic sources or (2) that low-degree melt from recycled oceanic crust reacts with peridotite in the presence of $\mathrm{CO}_{2}$, producing low-silica alkaline melt by olivine dissolution and orthopyroxene precipitation. These two hypotheses are plausible in terms of major elements. However, they have specific implications about the type and proportion of recycled lithologies present in the asthenosphere to explain the specific trace-element pattern of intraplate alkaline lavas. A third hypothesis for the formation of alkaline magmas is the melting of metasomatized lithosphere. In this model, the major- and trace-element signature of alkaline magma is not controlled by the asthenospheric source (i.e., the amount of oceanic crust or $\mathrm{CO}_{2}$ present in the asthenosphere), but by the petrological process that controls the percolation and differentiation of low-degree asthenospheric melts across the lithosphere. This process forms amphibole-bearing metasomatic veins that are a candidate source of alkaline rocks. This hypothesis offers an explanation for the generation of the Na-alkaline lavas with similar major- and trace-element composition that are observed worldwide and for the generation of $\mathrm{K}$ - and Na-alkaline magma observed in continental settings.
\end{abstract}

\footnotetext{
*Sebastien.Pilet@unil.ch

Pilet, S., 2015, Generation of low-silica alkaline lavas: Petrological constraints, models, and thermal implications, in Foulger, G.R., Lustrino, M., and King, S.D., eds., The Interdisciplinary Earth: A Volume in Honor of Don L. Anderson: Geological Society of America Special Paper 514 and American Geophysical Union Special Publication 71, p. 281-304, doi:10.1130/2015.2514(17). For permission to copy, contact editing @ geosociety.org. @ 2015 The Geological Society of America. All rights reserved.
} 
This hypothesis requires the formation of significant amounts of metasomatic veins within the lithosphere.

Qualitative analyses of the thermal implication of the potential models for the generation of alkaline rocks demonstrate that such magma requires low potential temperature (Tp: $1320{ }^{\circ} \mathrm{C}$ to $\left.1350{ }^{\circ} \mathrm{C}\right)$. If temperatures are higher, melting of the convecting mantle will erase any signature of low-degree melts produced from fertile mantle lithologies. This analysis suggests that a role for hot thermal plumes in the generation of intraplate volcanoes dominated by alkaline magmas is unrealistic.

\section{INTRODUCTION}

As noted by Gast (1968, p. 1082), "from the point of view of mantle process and chemical evolution of the mantle, alkaline volcanism is a very important process even if the abundance of such rocks is small at the Earth's surface". In particular, alkaline rocks have played an important role in the discussion about the existence of mantle plumes because these rocks are interpreted as low-degree melts produced at great depth (e.g., Green and Ringwood, 1967; Gast, 1968; Kushiro, 1968) and therefore could provide information about deep mantle processes. As indicated by Mitchell (1996), no consensus among petrologists exists for the precise definition of alkaline rocks. Here, we distinguish alkaline from tholeiitic (i.e., subalkaline) rocks using the reference line suggested by Irvine and Baragar (1971) (Fig. 1). Alkaline lavas are observed in different intraplate settings such as oceanic islands, intracontinental volcanoes, or continental rift zones (Fig. 2). It is important to emphasize that alkaline rocks are volumetrically minor in "large" oceanic islands such as Hawaii, Iceland, Azores, La Réunion, or Galápagos Islands compared with the dominant tholeiitic magmas there (Fig. 1B). In Hawaii, for example, alkaline lavas are restricted to pre-shield and post-shield periods (Frey et al., 1990). The basalt compositions observed in large igneous provinces (LIPs) are dominated by tholeiitic lavas and $\mathrm{MgO}$-rich lavas such as picrites, suggesting that the source of these rocks could reach a degree of partial melting significantly higher than required for the generation of alkaline lavas (e.g., Walter, 1998; Herzberg and Gazel, 2009; Heinonen and Luttinen, 2010).

The isotopic composition of alkaline rocks has been used to demonstrate that the Earth's mantle is heterogeneous on millimeter to kilometer scales (Chase, 1981; Allègre, 1982; Hofmann and White, 1982; Zindler and Hart, 1986; Hofmann, 1997). Nevertheless, there remains an ongoing debate about the petrological process responsible for alkaline lavas, and several models that are not mutually exclusive have been proposed. Alkaline magmas have been interpreted, for example, as low-degree melts from peridotite (e.g., Green, 1973), partial melts from lithologies such as recycled oceanic crust (e.g., Chase, 1981; Hofmann et al., 1986; Weaver, 1991; Chauvel et al., 1992), melting of peridotite and/or pyroxenite in the presence of $\mathrm{CO}_{2}$ (e.g., Eggler and Holloway, 1977; Wyllie, 1977; Hirose, 1997; Dasgupta and Hirschmann, 2007), or melt from metasomatized lithosphere (e.g., Lloyd and Bailey, 1975; Halliday et al., 1995; Niu and O'Hara, 2003; Pilet et al., 2008). The diversity of models is somewhat linked to the different petrological and geochemical constraints used to develop them. For example, the hypothesis suggesting alkaline magma formation by melting of recycled oceanic crust is mostly based on incompatible trace-element ratios and isotope constraints (e.g., Hofmann, 1997), while the hypothesis that alkaline melts represent low-degree melts from peridotite in presence of $\mathrm{CO}_{2}$ are based on experimental petrology (Brey and Green, 1975; Eggler and Holloway, 1977; Wyllie, 1977; Dasgupta and Hirschmann, 2007).

The main goal of this paper is evaluate the different hypotheses for the origin of alkaline mafic magma using both petrological and geochemical constraints. Our analysis is based on the following assumptions: any model for the generation of alkaline mafic magmas needs to explain (1) why alkaline mafic rocks are characterized by lower $\mathrm{SiO}_{2}$ contents that mid-ocean-ridge basalt (MORB); (2) why these rocks cover a wide range of composition from nephelinite to alkali basalts and sometimes tholeiite; (3) why alkaline mafic rocks are always characterized by high incompatible trace-element contents; and (4) why alkaline mafic rocks characterized by similar major-element composition show variable incompatible trace-element ratios and isotopic compositions. Our discussion will also focus on the compositional similarities of alkaline lavas erupted in intraoceanic, intracontinental, and rift settings. Any model for the origin of alkaline lavas needs to be applicable to the different settings where these rocks are observed. Finally, these constraints will be used to discuss the thermal structure of the mantle sources and whether or not thermal plumes are involved.

\section{PETROLOGICAL AND GEOCHEMICAL CONSTRAINTS RELATED TO THE GENERATION OF LOW-SILICA ALKALINE BASALTS}

The question of the origin of alkaline lavas will be addressed using compilation of lava composition from the GEOROC 

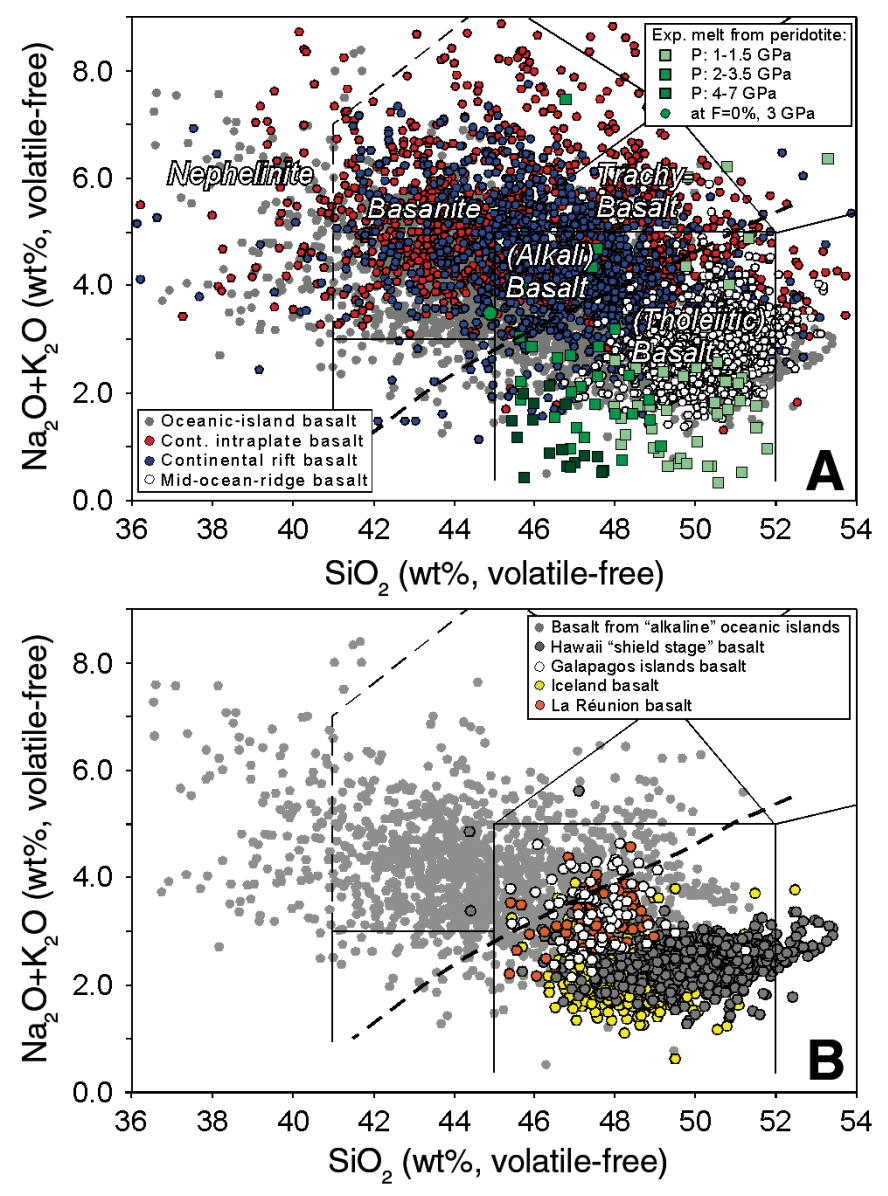

database (http://georoc.mpch-mainz.gwdg.de/georoc/) for oceanisland and intraplate and rift continental settings (Fig. 2). Different filters have been used: first, only analyses where major-element compositions are provided have been selected; second, analyses showing sums of major elements (excluding loss on ignition) less than $97 \mathrm{wt} \%$ and exceeding $102 \mathrm{wt} \%$ have been removed; and
Figure 1. (A) Total alkali versus $\mathrm{SiO}_{2}$ (volatile-free) diagrams for ocean-island basalts, continental intraplate basalts, continental rift basalts, and mid-ocean-ridge basalts compared to experimental melts produced from peridotite at various pressures $(P, 1-7 \mathrm{GPa}$ ) (Hirose and Kushiro, 1993; Kushiro, 1996; Walter, 1998; Wasylenki et al., 2003). The incipient partial melt $(F \sim 0 \%)$ of garnet peridotite at $3 \mathrm{GPa}$ from Davis et al. (2011) is given for reference. (B) Total alkali versus $\mathrm{SiO}_{2}$ (volatile-free) diagrams for ocean-island basalts compared to tholeiitic lavas from Iceland, main shield stage at Hawaii, Galápagos Islands, and La Réunion. All basalts have $\mathrm{MgO}$ content between 8 and $15 \mathrm{wt} \%$ and $\mathrm{Na}_{2} \mathrm{O} / \mathrm{K}_{2} \mathrm{O}<0.8$. The subdivision between alkaline and subalkaline (tholeiitic) lavas is made using the reference line suggested by Irvine and Baragar (1971) (black dashed line in A and B).

third, only rocks characterized by $\mathrm{MgO}$ content between 8 and $15 \mathrm{wt} \%$ have been used to limit the effect of fractional crystallization or olivine accumulation on lava composition. We have also restricted our discussion to alkaline lavas characterized by $\mathrm{K}_{2} \mathrm{O} / \mathrm{Na}_{2} \mathrm{O}$ ratios $<0.8$ in order to avoid comparison of rocks produced by different sources. The implications of K-rich rocks in continental settings on the general framework of alkaline magma generation will be discussed in the last part of the paper. MORBs selected from the PetDB database (http://www.earthchem.org/ petdb) are also presented for comparison in the different figures. Recycled oceanic crust (i.e., MORB + oceanic gabbro) is frequently considered as a potential source lithology for intraplate basalts. In order to evaluate the complete range of MORB composition before recycling, the figures show MORB data without applying the filters related to $\mathrm{MgO}$ content and $\mathrm{K}_{2} \mathrm{O} / \mathrm{Na}_{2} \mathrm{O}$ ratio used for the intraplate lavas. We have not shown the composition of oceanic gabbro in the figures because this addition compromises their legibility. Nevertheless, almost all the conclusions drawn using MORB composition apply also to gabbros.

Figure 1A shows basalt composition for ocean-island, intracontinental, and rift settings compared to MORB using the above filters. The intraplate lavas show compositions ranging from nephelinite-basanite, characterized by low- $\mathrm{SiO}_{2}$ and high

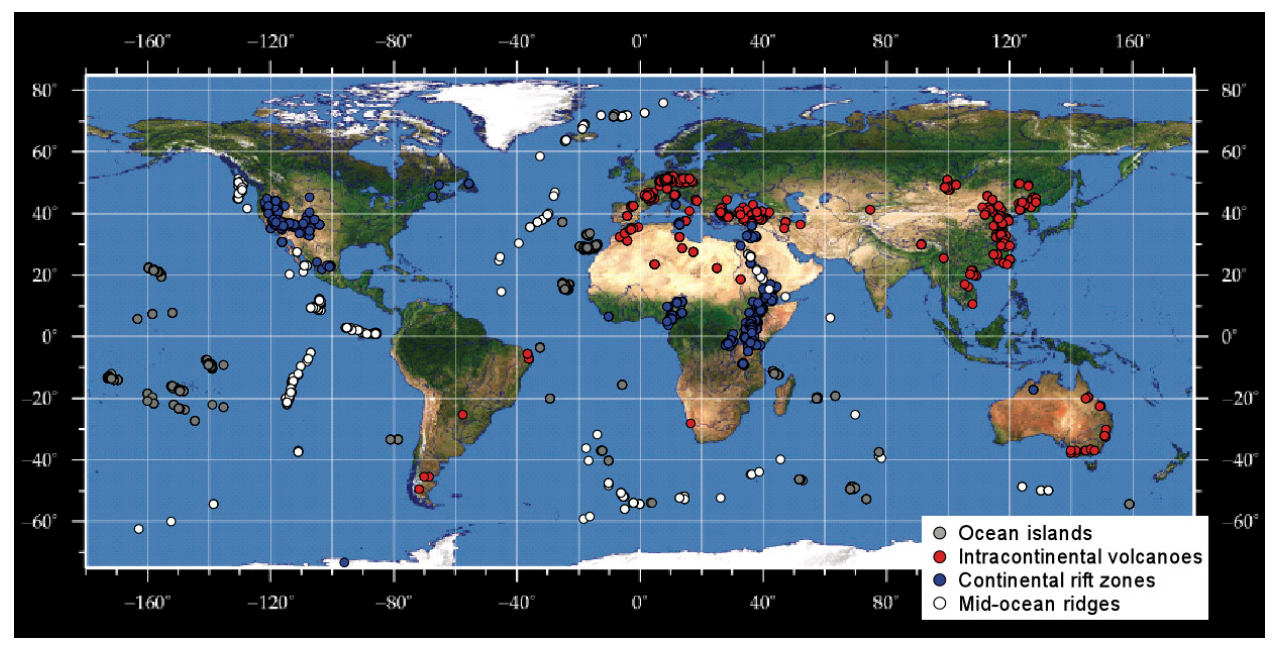

Figure 2. World map showing locations of the selected basalts. Grey points are oceanic intraplate basalts; red points, intracontinental basalts; blue points, continental rift basalts; white points, midocean-ridge basalts (MORBs). Data were selected from GEOROC (http:// georoc.mpch-mainz.gwdg.de/georoc/) and PetDB (http://www.earthchem.org/ petdb) databases for intraplate basalts and the MORBs respectively. 
alkali contents, to trachybasalt- alkali basalt and subalkalic tholeiitic basalts with higher silica and lower alkali contents. In comparison, tholeiitic lavas from mid-ocean ridges show a distinctly narrower compositional range (48-52 wt $\% \mathrm{SiO}_{2}$ ) and lower total alkali content $(<4 \mathrm{wt} \%)$.

A clear distinction exists between mafic magma emitted in large oceanic islands such as Hawaii (shield stage), Iceland, La Réunion, or the Galápagos and that emitted in smaller islands. As indicated in Figure 1B, the lava emitted in large islands is dominated by silica-saturated tholeiites, while in smaller islands (and intracontinental settings) the complete range of mafic lavas is observed. It is important to note that this compositional range is present in most single volcanic edifices and represents one important characteristic of so-called alkaline volcanoes. In the following discussion, we use the generic term "alkaline basalt" to encompass the compositional range of these alkaline volcanoes.

No significant compositional difference is observed between alkaline rocks from continental versus oceanic settings, although a slightly higher alkali content for a given $\mathrm{SiO}_{2}$ is observed in continental settings (Fig. 1A). This compositional similarity between alkaline rocks from different settings is valid for all major elements including $\mathrm{K}_{2} \mathrm{O}, \mathrm{CaO}, \mathrm{Al}_{2} \mathrm{O}_{3}$, and $\mathrm{TiO}_{2}$.

Comparison of intraplate lavas and MORBs with partial melting experiments produced from nominally dry peridotite at various pressures (1-7 GPa) shows one of the major differences between silica-poor alkaline lavas and tholeiites. Peridotite melting experiments demonstrate that the generation of MORB-like tholeiites can be reproduced by partial melting of peridotite representing the convecting mantle at relatively low pressure (1$1.5 \mathrm{GPa}$; e.g., Wasylenki et al., 2003). These experimental data also indicate that alkaline rocks with intermediate $\mathrm{SiO}_{2}$ content $(\sim 45 \mathrm{wt} \%)$ can be produced by a low degree of partial melting of nominally dry peridotite at asthenospheric pressures $(>3 \mathrm{GPa})$, but low-Si alkali basalts cannot. Experiments on incipient partial melts from garnet peridotite (Davis et al., 2011; Davis and Hirschmann, 2013) confirm that ultrabasic alkaline magmas such as nephelinite cannot be produced from four-phase peridotite, suggesting that the addition of volatiles or the presence of other lithologies in the source region is required to explain the specific composition of these rocks.

A second characteristic feature of nephelinite and basanite is their high content of incompatible trace elements (Gast, 1968). Figure 3A shows trace-element contents normalized to the composition of the primitive mantle from McDonough and Sun (1995) for oceanic and continental low-silica alkaline lavas $\left(\mathrm{SiO}_{2}<45 \mathrm{wt} \%\right.$, average $\left.\pm 1 \sigma\right)$. Low-Si alkaline lavas from both settings show similar patterns with high contents of very incompatible trace elements $(\mathrm{Ba}, \mathrm{Nb}, \mathrm{La})$, negative anomalies for $\mathrm{Rb}, \mathrm{K}$, and $\mathrm{Pb}$ compared with elements with a similar degree of incompatibility (e.g., $\mathrm{Ba}, \mathrm{Nb}, \mathrm{Ce}$, respectively), and similar slope and content for REE. Lustrino (2011) showed similar traceelement content homogeneity in alkaline mafic magmas using Cenozoic basaltic lavas from the circum-Mediterranean continental and oceanic area. The trace-element pattern of alkaline lavas is frequently interpreted as being due to low degrees melt from a garnet peridotite source (Gast, 1968). Assuming such a hypothesis, we have calculated, using the non-modal batchmelting equation, the composition of the source for low-Si alkaline ocean-island basalts (OIBs) (Fig. 3B). The source calculations are constrained by mineralogical and melting mode of the peridotitic source including minor amounts of sulfide, the degree of partial melting at which the melt is produced, the depth of melting, and the mineral-liquid distribution coefficients $\left(\mathrm{D}^{\mathrm{min} / \mathrm{liq}}\right)$. The model developed by Baker et al. (2008) was used to calculate the modal peridotite proportion, while melting experiments at $3 \mathrm{GPa}$ (Walter, 1998) corresponding to the pressure at the base of a thick oceanic lithosphere were used to constrain the melting mode. Modal abundance in the source, melting mode, and the $\mathrm{D}^{\mathrm{min} / \mathrm{liq}}$ for olivine, clinopyroxene, orthopyroxene, and garnet are given in Pilet et al. (2011). All of these parameters are listed in Table 1 . The degree of partial melting at which the nephelinites or
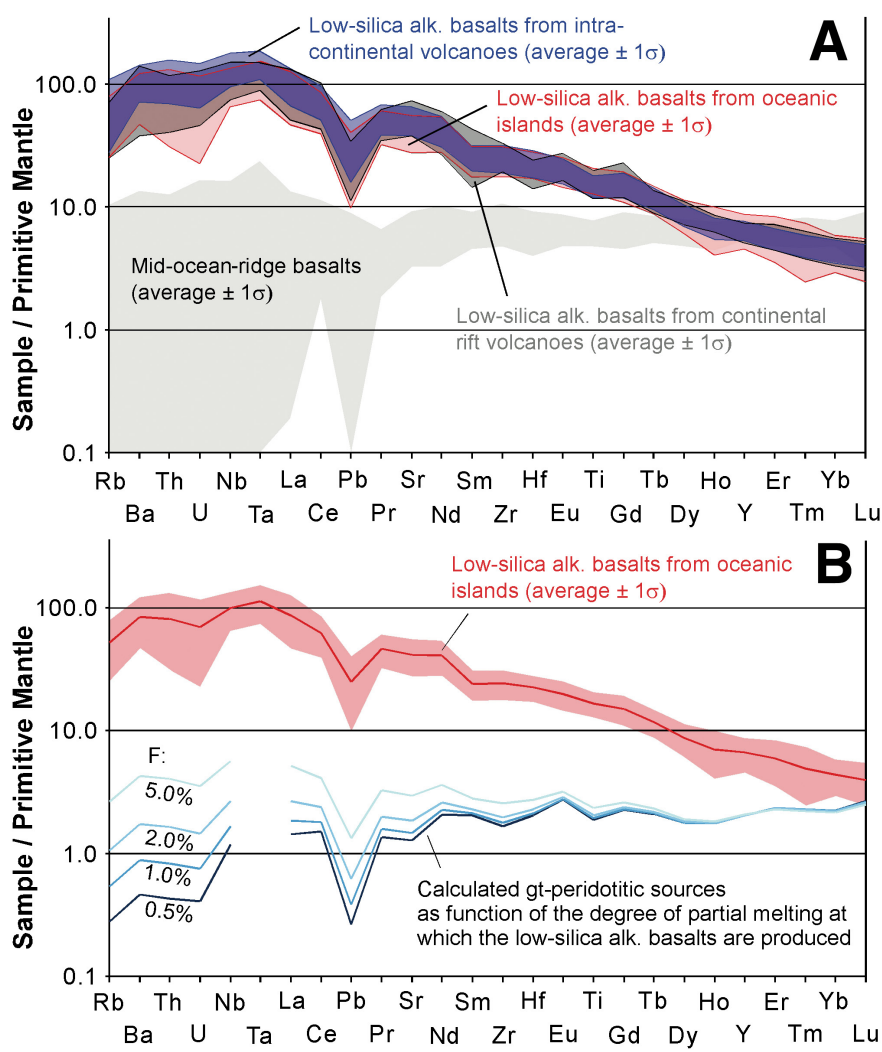

Figure 3. (A) Trace-element contents (normalized to primitive mantle; McDonough and Sun, 1995) of low-silica alkaline basalt $\left(\mathrm{SiO}_{2}<45 \mathrm{wt} \%\right.$; $\left.\mathrm{MgO}, 8-15 \mathrm{wt} \%\right)$ observed in oceanic island, intracontinental, and continental rift settings. All fields correspond to the composition averages $\pm 1 \sigma$. The composition of mid-ocean-ridge basalt (average $\pm 1 \sigma, \mathrm{MgO}>8 \mathrm{wt} \%$ ) is also shown for reference. (B) Trace-element contents (normalized to primitive mantle) of lowsilica alkaline basalt $\left(\mathrm{SiO}_{2}<45 \mathrm{wt} \% ; \mathrm{MgO}, 8-15 \mathrm{wt} \%\right)$ and hypothetical source compositions assuming that alkaline basalt is produced by partial melting of garnet $(\mathrm{gt})$ peridotite at melting degree $(F)$ varying from $0.5 \%$ to $5 \%$. See text for details of the calculation. 
TABLE 1. PARAMETERS RELATED TO THE LOW-SILICA ALKALINE BASALT SOURCE ESTIMATION (FIG. 3B)

\begin{tabular}{|c|c|c|c|c|c|c|c|c|c|c|c|c|}
\hline \multicolumn{13}{|c|}{ Melting parameters } \\
\hline Olivine & \multicolumn{2}{|c|}{0.594} & \multicolumn{2}{|c|}{0.08} & & & & & & & & \\
\hline Clinopyroxene & \multicolumn{2}{|c|}{0.106} & \multicolumn{2}{|l|}{0.81} & & & & & & & & \\
\hline Garnet & \multicolumn{2}{|c|}{0.105} & \multicolumn{2}{|c|}{0.3} & & & & & & & & \\
\hline Sulfide & \multicolumn{2}{|c|}{$0.00037^{\S}$} & \multicolumn{2}{|c|}{$0.0037^{\S}$} & & & & & & & & \\
\hline \multicolumn{13}{|c|}{ Mineral/liquid distribution coefficients $\left(D^{\text {min/liq }}\right)$ used in the calculation ${ }^{\#}$} \\
\hline Clinopyroxene & 0.0007 & 0.00068 & 0.0008 & 0.0008 & 0.0077 & 0.0536 & 0.0858 & 0.01 & 0.1 & 0.13 & 0.19 & 0.29 \\
\hline Orthopyroxene & 0.0006 & 0.001 & 0.00 & 0.00 & 0.0031 & 0.002 & 0.003 & 0.0013 & 0.0048 & 0.007 & 0.0068 & 0.01 \\
\hline Garnet & 0.0007 & 0.0007 & 0.0015 & 0.005 & 0.02 & 0.01 & 0.021 & 0.0005 & 0.045 & 0.006 & 0.087 & 0.217 \\
\hline \multirow[t]{2}{*}{ Sulfide } & 0.0001 & 0.0001 & 0.0001 & 0.0001 & 0.0001 & 0.0001 & 0.0001 & 10 & 0.0001 & 0.0001 & 0.0001 & 0.0001 \\
\hline & $\mathrm{Zr}$ & $\mathrm{Hf}$ & $\mathrm{Eu}$ & $\mathrm{Ti}$ & $\mathrm{Gd}$ & $\mathrm{Tb}$ & Dy & $\mathrm{Ho}$ & $\mathrm{Y}$ & Er & $\mathrm{Yb}$ & $\mathrm{Lu}$ \\
\hline Olivine & 0.010 & 0.005 & 0.002 & 0.020 & 0.002 & 0.002 & 0.002 & 0.002 & 0.005 & 0.002 & 0.0015 & 0.0015 \\
\hline \multicolumn{13}{|c|}{ 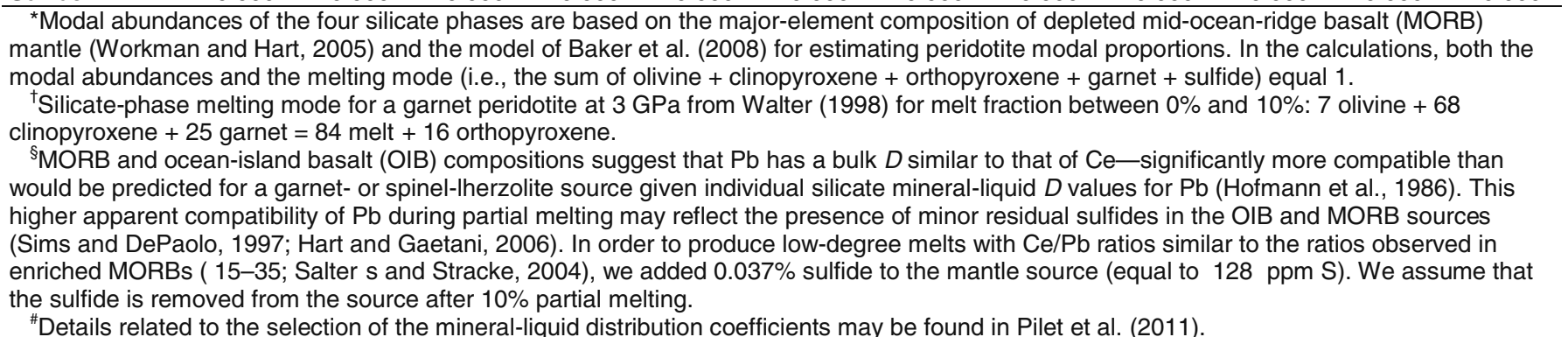 } \\
\hline
\end{tabular}

basanites are produced is more difficult to constrain. For that, we used variable $F$ (from $0.5 \%$ to $5 \%$ ) to investigate the influence of this parameter on the calculated source composition.

One important observation related to these calculations is that the source of low-Si alkaline basalts needs to be more enriched for most incompatible elements than the primitive mantle estimate (Fig. 3B) and that the problem is not related to the strongly incompatible elements but rather to intermediately incompatible elements such as heavy rare earth elements (HREE), Ti, and Y. The concentration of strongly incompatible elements such as U, Th, and light rare earth elements (LREE) is controlled by the degree of partial melting $(F)$ at which the liquid is produced, so it is always possible to suggest that alkaline lavas are produced at extremely low degrees of partial melting $(<0.5 \%)$ to satisfy the content of these elements in the target melts. At the other extreme, the parameter that limits the degree of melt enrichment for intermediate incompatible elements is not the degree of partial melting $(F)$ but the distribution coefficients $\left(D_{0}\right.$, $\left.P_{0}\right)$ of the melting assemblage. This calculation is fundamental for the discussion about the origin of alkaline rocks because it demonstrates that the convecting mantle, even assuming a primitive mantle composition, is not sufficiently enriched in incompatible trace elements to produce the compositional range observed in alkaline rocks. Therefore, source enrichment processes are a prerequisite for the generation of low-Si alkaline rocks. In addition, this source enrichment, previously shown by Willbold and Stracke (2006), Prytulak and Elliott (2007), and Adam and Green (2011), needs to be similar in every setting.

A third characteristic of alkaline mafic lavas is their large isotopic variation range with respect to MORBs (e.g., Zindler and Hart, 1986; Hofmann, 1997; Fig. 4). Many studies (Hofmann and White, 1982; Hofmann et al., 1986; Chauvel et al., 1992; Halliday et al., 1995; Willbold and Stracke, 2006; Stracke, 2012) have focused on the differences in trace-element ratios observed in OIB characterized by distinct isotope compositions (i.e., enriched mantle [EM] or HIMU [high- $\mu$ mantle with $\mu={ }^{238} \mathrm{U} /{ }^{204} \mathrm{~Pb}$ ratio]) to constrain the source characteristics. These studies conclude that, to explain the variable isotopic and trace-element ratios observed in OIBs, the sources of these rocks need to incorporate lithospheric material recycled into the convecting mantle and potentially stored at the base of the mantle for 1-2 b.y.

Various authors have suggested, however, that the difference in isotopic ratios between OIBs and MORBs seems not to be related to a difference in their respective source compositions, but rather to the melting process which allows the mantle 

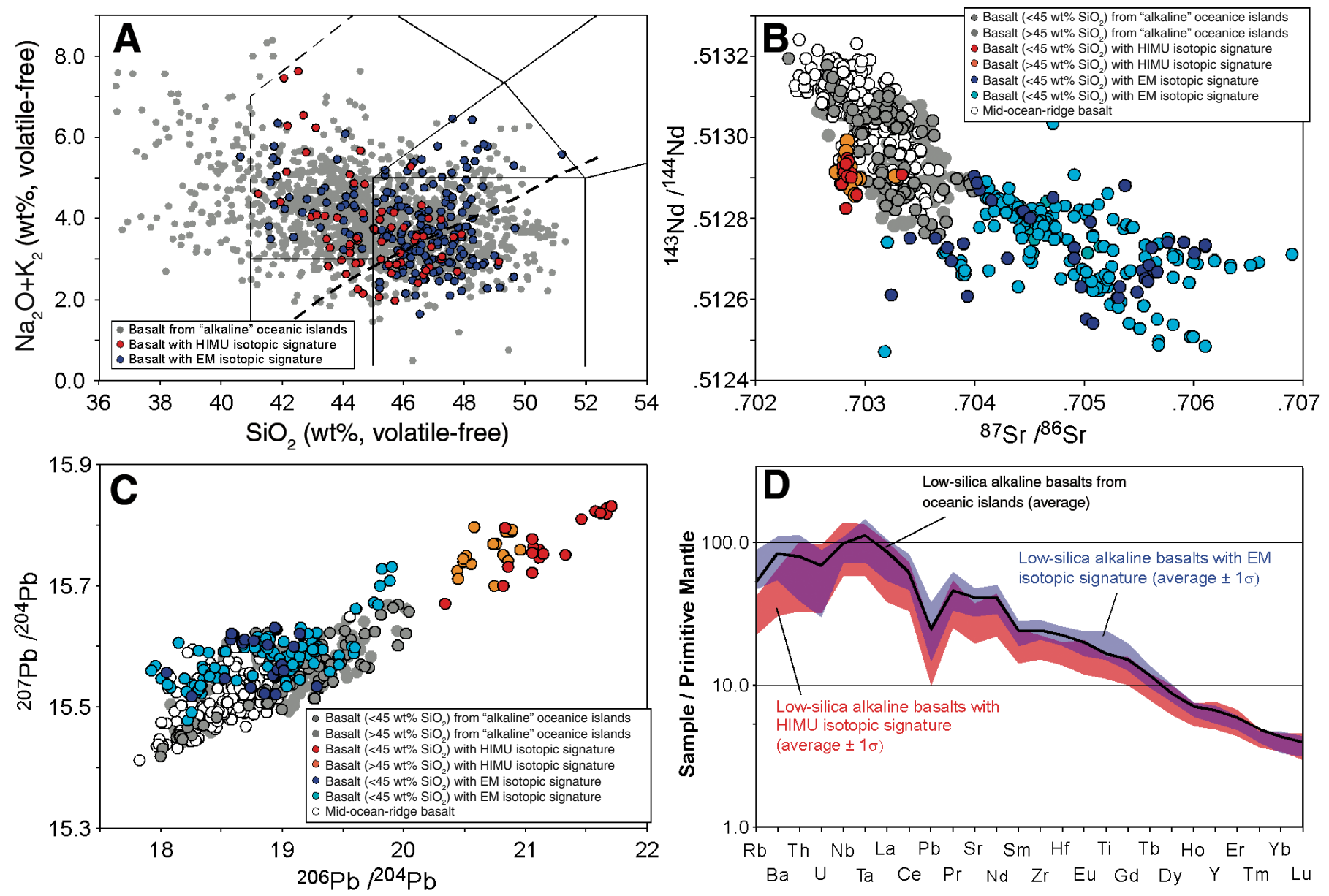

Figure 4. (A) Total alkali versus $\mathrm{SiO}_{2}$ (volatile-free) diagrams for "alkaline" ocean-island basalts (all ocean-island basalts excluding tholeiite lavas from Iceland, Hawaii, Galápagos Islands, and La Réunion) compared to ocean-island basalts characterized by HIMU or EM isotopic signature (EM if ${ }^{143} \mathrm{Nd} /{ }^{144} \mathrm{Nd}<0.51275$ or ${ }^{87} \mathrm{Sr} /{ }^{86} \mathrm{Sr}>0.704$; HIMU if $\left.{ }^{206} \mathrm{~Pb} /{ }^{204} \mathrm{~Pb}>20.3\right)$. (B-C) ${ }^{143} \mathrm{Nd} /{ }^{144} \mathrm{Nd}$ versus ${ }^{87} \mathrm{Sr} /{ }^{86} \mathrm{Sr}(\mathrm{B})$ and ${ }^{207} \mathrm{~Pb} /{ }^{204} \mathrm{~Pb}$ versus ${ }^{206} \mathrm{~Pb} /{ }^{204} \mathrm{~Pb}(\mathrm{C})$ isotopic diagrams for "alkaline" ocean-island basalts compared to mid-ocean-ridge basalts and basalts characterized by HIMU and EM isotopic composition. All ocean-island basalts have been distinguished by their $\mathrm{SiO}_{2}$ content (higher or lower that $45 \mathrm{wt} \%$ ). These diagrams demonstrate that low-silica alkali basalts cover the complete range of isotopic compositions. (D) Trace-element contents (normalized to primitive mantle; McDonough and Sun, 1995) of low-silica alkaline basalts ( $\mathrm{SiO}_{2}<45 \mathrm{wt} \% ; \mathrm{MgO}, 8-15$ wt\%) characterized by HIMU or EM isotopic composition (average $\pm 1 \sigma$ ). The average trace-element pattern (black line) of all low-silica alkaline basalts is shown for comparison.

and its enclosing fertile components to melt to a larger extent below oceanic ridges than in intraplate settings where the thickness of the lithosphere limits the extent of melting of the heterogeneous mantle (e.g., Ellam, 1992; Meibom and Anderson, 2004; Ito and Mahoney, 2005; Niu et al., 2011). Current analyses of the origin of OIBs based on isotopic composition and trace-element ratios (Hofmann and White, 1982; Hofmann et al., 1986; Chauvel et al., 1992; Halliday et al., 1995; Willbold and Stracke, 2006; Stracke, 2012) have made no distinction between low-Si alkaline and more silica-rich lavas. Figure 4A indicates that OIBs characterized by HIMU to EM isotopic signatures are not restricted to specific major-element compositions, but cover the complete basaltic range in terms of silica and alkali content. Low-Si basalts $\left(<45 \mathrm{wt} \% \mathrm{SiO}_{2}\right)$ also overlap the complete $\mathrm{Sr}, \mathrm{Nd}$, and $\mathrm{Pb}$ isotopic ranges defined by OIBs (Figs. 4B, 4C).
Trace-element patterns for low-Si alkaline basalts characterized by HIMU or EM isotope composition (Fig. 4D) show distinct enrichments for $\mathrm{Rb}, \mathrm{Ba}, \mathrm{K}$, and $\mathrm{Pb}$ as previously pointed out by Weaver (1991), Chauvel et al. (1992), Halliday et al. (1995), and Willbold and Stracke (2006), but the other incompatible elements including $\mathrm{U}, \mathrm{Th}, \mathrm{Nb}$, and REE do not show variation correlated to isotope composition. Figure 4D also indicates that the general trace-element patterns of HIMU and EM basalts are mostly indistinguishable from the pattern of low-Si alkaline basalts observed worldwide (Fig. 3A). Pilet et al. (2011) previously showed that extreme values for incompatible trace-element ratios considered as diagnostic for EM or HIMU basalts, such $\mathrm{Ba} / \mathrm{Nb}$ or $\mathrm{Ce} / \mathrm{Pb}$, are not restricted to basalts characterized by extreme isotopic composition such HIMU or EM, but are also observed in oceanic or continental alkaline lavas with "normal" 
isotopic composition. These observations are important constraints for any model seeking to explain the origin of alkaline lavas_-such a model needs to explain why alkaline mafic rocks characterized by various isotopic composition show such similar major- and trace-element compositions.

The presence of recycled components in the source of OIBs is a well-accepted hypothesis. The current discussion is focused on the type of component(s) present in the source of OIBs. The subduction of oceanic lithosphere is the most important process that recycles shallow material into the convecting mantle, but other processes certainly contribute (e.g., subcontinental lithospheric mantle and lower continental crust delamination, or subduction-enriched mantle mixed back into the upper mantle; Arndt and Goldstein, 1989; Elliott et al., 2006; Panter et al., 2006; Willbold and Stracke, 2010; Stracke, 2012). Recycled oceanic crust ( \pm sediments) in the source of OIBs is used in numerous studies to explain isotopic variability (e.g., Chase, 1981; Hofmann and White, 1982; Weaver, 1991; Chauvel et al., 1992), even if some authors call into question the details (e.g., Niu and O'Hara, 2003). Other hypotheses favor the presence of metasomatized continental or oceanic lithospheric mantle to explain the composition of OIBs (Hawkesworth et al., 1986; Halliday et al., 1995; McKenzie and Onions, 1995; Niu and O’Hara, 2003; Pilet et al., 2005). Nevertheless, all these studies generally neglect the questions of whether their models predict the correct majorelement composition and whether the degree of trace-element enrichment of the erupted lavas is satisfied.

\section{Partial Melting of Recycled Oceanic Crust}

Various studies have focused on liquid compositions produced by the melting of pyroxenites at mantle pressure. Figure 5 compares the $\mathrm{Na}_{2} \mathrm{O}+\mathrm{K}_{2} \mathrm{O}$ and $\mathrm{SiO}_{2}$ content of melts produced in these experiments with the composition of OIBs and MORBs. In this figure, we have distinguished melts derived from silica-excess pyroxenites, characterized by a subsolidus assemblage comprising pyroxene and garnet plus plagioclase and quartz/coesite, from silica-deficient pyroxenites (pyroxene and garnet plus olivine and spinel) on the thermal divide that controls their respective melting behaviors. Kogiso et al. (2004) and Lambart et al. (2013) provided comprehensive reviews of pyroxenite melting. Both types of pyroxenite have been linked to the recycling of oceanic crust; the composition of Si-excess pyroxenites used in experiments has been selected to be representative of the upper and lower oceanic crust (i.e., MORBs or gabbro), while Si deficient pyroxenite could represent the potential composition of recycled MORB after Si extraction by either (1) hybridization with peridotite; (2) metasomatism by silica-deficient melts such as carbonatite; or (3) removal of lowpressure partial melts or fluids (Hirschmann et al., 2003). The melting of Si-excess pyroxenites produces liquids generally richer in silica than the initial starting composition (Green et al., 1967; Pertermann and Hirschmann, 2003b; Keshav et al., 2004; Yaxley and Sobolev, 2007; Lambart et al., 2013), the opposite of Si-deficient pyroxenite which produces melts with similar or lower silica content than the starting composition (Hirschmann et al., 2003; Lambart et al., 2013), except at high pressure ( $\geq 5 \mathrm{GPa}$ ) where garnet is the major residual phase (Kogiso et al., 2003) (Fig. 5). Partial melting experiments on Si-excess pyroxenites are consistent with MORB-like pyroxenites in the source of Si-rich tholeiite from Hawaii and other large oceanic islands (Sobolev et al., 2005, 2007) or LIPs (Takahashi et al., 1998) but seem inconsistent with the composition of low-Si alkaline lavas observed in intraplate settings (Fig. 5). Any model aiming to explain the origin of low-Si alkaline lavas by partial melting of Si-excess pyroxenite sources representative of the upper or lower oceanic crust (MORB or gabbro respectively) without involving additional processes that could modify the starting pyroxenitic composition or the partial melt composition before it reaches the surface seems, therefore, unrealistic. In contrast, the melting of Si-deficient pyroxenites produces liquids that are closer to OIB composition in term of $\mathrm{SiO}_{2}$ and total alkali content (Fig. 5).

The compositions of pyroxenite melts are generally compared to OIBs using $\mathrm{CaO}, \mathrm{MgO}, \mathrm{Al}_{2} \mathrm{O}_{3}, \mathrm{SiO}_{2}$, and sometimes $\mathrm{TiO}_{2}$ (e.g., Hirschmann et al., 2003; Kogiso et al., 2003). Here we compare experimental melts to specific major-element ratios that are distinctive of the MORB versus OIB composition $\left(\mathrm{Al}_{2} \mathrm{O}_{3} / \mathrm{TiO}_{2}\right.$ and $\mathrm{Na}_{2} \mathrm{O} / \mathrm{K}_{2} \mathrm{O}$; Figs. 6A, 6B). MORBs show highly variable $\mathrm{Al}_{2} \mathrm{O}_{3} / \mathrm{TiO}_{2}$ and $\mathrm{Na}_{2} \mathrm{O} / \mathrm{K}_{2} \mathrm{O}$ ratios compared with alkaline sodic magmas characterized by mostly constant ratios (Fig. 6).

Experimental melts from Si-deficient pyroxenites are characterized by variable $\mathrm{Al}_{2} \mathrm{O}_{3} / \mathrm{TiO}_{2}$ and $\mathrm{Na}_{2} \mathrm{O} / \mathrm{K}_{2} \mathrm{O}$ ratios (Figs. $6 \mathrm{C}, 6 \mathrm{D})$, and only very few pyroxenite-derived melts have ratios similar to those observed in low-Si alkaline basalts. One possible explanation for this misfit is the high degree of partial melting at which pyroxenite experimental melts are produced. However, thermodynamic models for the melting of a heterogeneous mantle composed of pyroxenitic lithologies embedded in peridotite in an upwelling adiabatic context predict that the degree of partial melting reached by the pyroxenite will be high (Hirschmann and Stolper, 1996; Phipps Morgan, 2001; Ito and Mahoney, 2005; Stolper and Asimow, 2007). In addition, MORBs show highly variable $\mathrm{Al}_{2} \mathrm{O}_{3} / \mathrm{TiO}_{2}$ ratios, and this ratio is unlikely to be fractionated during subduction processes ( $\mathrm{Al}$ and $\mathrm{Ti}$ are considered to be mostly immobile in subduction fluids; Kessel et al., 2005a, 2005b). Thus, regarding the large composition range of MORB (Fig. 6A), the melting of MORB eclogite is unlikely to produce melts with mostly constant $\mathrm{Al}_{2} \mathrm{O}_{3} / \mathrm{TiO}_{2}$ ratios as observed in low$\mathrm{Si}$ alkaline lavas. $\mathrm{Na}_{2} \mathrm{O} / \mathrm{K}_{2} \mathrm{O}$ ratios of experimental pyroxenitic melts are also highly variable. This variability is related to the starting material compositions, the degree of partial melting at which experimental melts are produced, and the pressure at which experiments are performed $(2.5-5 \mathrm{GPa})$ as the compatibility of $\mathrm{Na}_{2} \mathrm{O}$ in clinopyroxene increases with pressure. Considering that MORBs and oceanic gabbros do not contain significant amounts of $\mathrm{K}_{2} \mathrm{O}$ (except for highly altered MORBs), and that pyroxenites are expected to melt to a high degree during mantle 


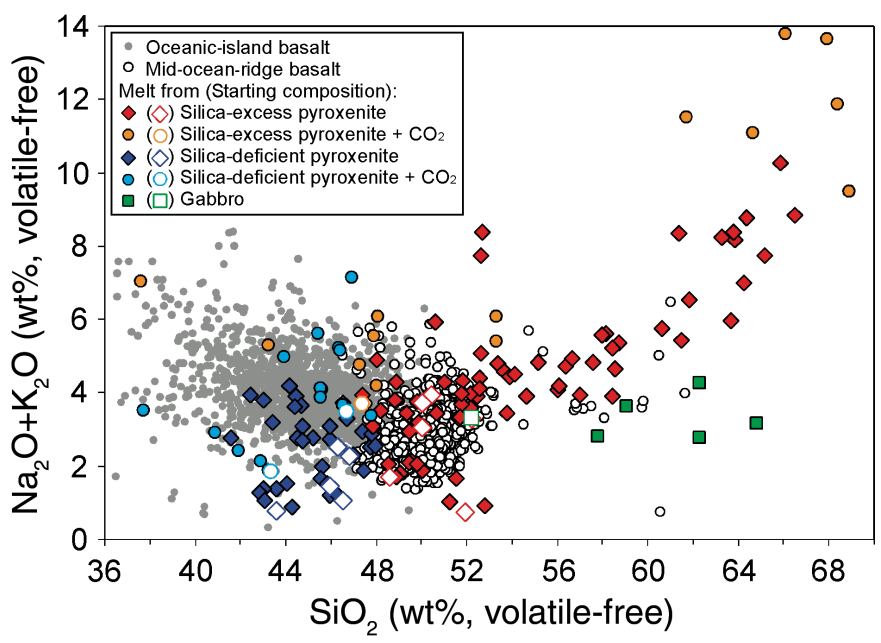

Figure 5. Total alkali versus $\mathrm{SiO}_{2}$ (volatile-free) diagrams for oceanisland basalts and mid-ocean-ridge basalts compared to high-pressure experimental melts produced from silica-excess pyroxenites (Pertermann and Hirschmann, 2003a; Spandler et al., 2008; Yaxley and Green, 1998), silica-saturated pyroxenite in presence of $\mathrm{CO}_{2}$ (Kiseeva et al., 2012), silica-deficient pyroxenites (Hirschmann et al., 2003; Kogiso et al., 2003; Keshav et al., 2004; Kogiso and Hirschmann, 2006; Lambart et al., 2009), silica-deficient pyroxenites in the presence of $\mathrm{CO}_{2}$ (Dasgupta et al., 2006; Gerbode and Dasgupta, 2010), and gabbro (Yaxley and Sobolev, 2007). All basalts have MgO content between 8 and $15 \mathrm{wt} \%$.
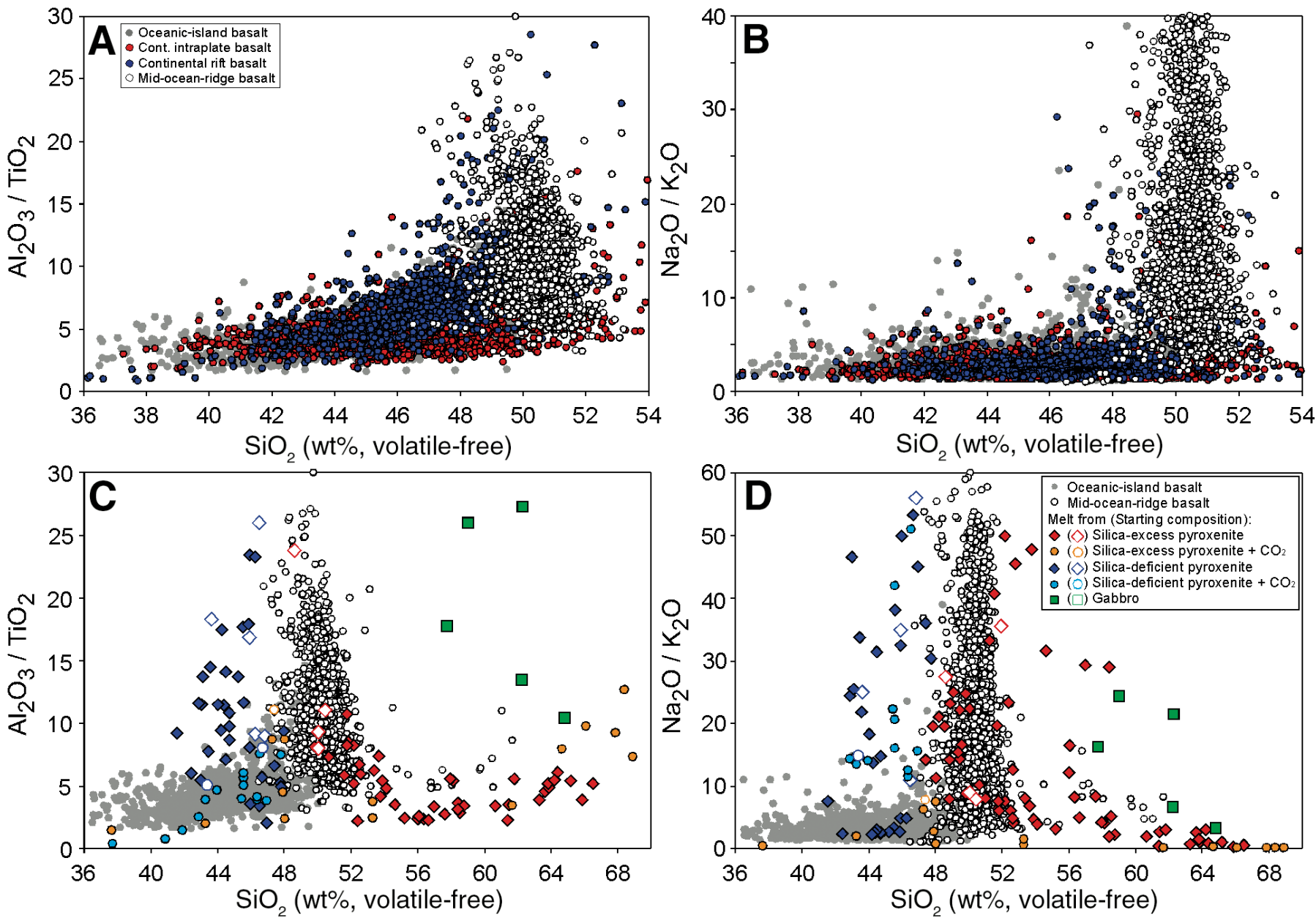

Figure 6. (A-B) $\mathrm{Al}_{2} \mathrm{O}_{3} / \mathrm{TiO}_{2}$ versus $\mathrm{SiO}_{2}$ (volatile-free) (A) and $\mathrm{Na}_{2} \mathrm{O} / \mathrm{K}_{2} \mathrm{O}$ versus $\mathrm{SiO}_{2}$ (volatile-free) (B) diagrams for ocean-island basalts, continental intraplate basalts, and continental rift basalts compared to mid-ocean-ridge basalts $(\mathrm{MORBs})$. $(\mathrm{C}-\mathrm{D}) \mathrm{Al}_{2} \mathrm{O}_{3} / \mathrm{TiO}_{2}$ versus SiO${ }_{2}$ (volatilefree) (C) and $\mathrm{Na}_{2} \mathrm{O} / \mathrm{K}_{2} \mathrm{O}$ versus $\mathrm{SiO}_{2}$ (volatile-free) (D) diagrams for ocean-island basalts compared to experimental melts produced from silicasaturated pyroxenite (Yaxley and Green, 1998; Pertermann and Hirschmann, 2003a; Spandler et al., 2008), silica-saturated pyroxenite in the presence of $\mathrm{CO}_{2}$ (Kiseeva et al., 2012), silica-deficient pyroxenite (Hirschmann et al., 2003; Kogiso et al., 2003; Keshav et al., 2004; Kogiso and Hirschmann, 2006; Lambart et al., 2009), silica-deficient pyroxenite in the presence of $\mathrm{CO}_{2}$ (Dasgupta et al., 2006; Gerbode and Dasgupta, 2010), and gabbro (Yaxley and Sobolev, 2007). All intraplate basalts have $\mathrm{MgO}$ content between 8 and $15 \mathrm{wt} \%$ while no filter is applied for MORB data. 
upwelling, it seems unlikely that the low $\mathrm{Na}_{2} \mathrm{O} / \mathrm{K}_{2} \mathrm{O}$ ratio of low$\mathrm{Si}$ alkaline basalts is related to the melting of pyroxenite derived from subducted oceanic crust.

The addition of $\mathrm{CO}_{2}$ to the system, either via hydrothermal carbonate veins crosscutting oceanic crust (Dasgupta et al., 2006) or by carbonate-fluxed MORB-like pyroxenite (Gerbode and Dasgupta, 2010), decreases the pyroxenite solidus temperature relative to volatile-free melting (Dasgupta et al., 2004; Kiseeva et al., 2012) (Figs. 5, 6B, 6D). Melts produced at various degrees of partial melting from Si-deficient pyroxenite $+\mathrm{CO}_{2}$ (Dasgupta et al., 2006; Gerbode and Dasgupta, 2010) or from Si-excess pyroxenite $+\mathrm{CO}_{2}$ (Kiseeva et al., 2012) show significant variations in their composition, in particular for $\mathrm{SiO}_{2}$ content and $\mathrm{Al}_{2} \mathrm{O}_{3} / \mathrm{TiO}_{2}$ and $\mathrm{Na}_{2} \mathrm{O} / \mathrm{K}_{2} \mathrm{O}$ ratios. It is currently difficult to constrain the exact effect of $\mathrm{CO}_{2}$ addition to pyroxenite melting because of the limited number of studies. The existence of coexisting immiscible silicate and carbonatitic melts (Dasgupta et al., 2006; Gerbode and Dasgupta, 2010; Kiseeva et al., 2012) at low melt fraction complicates the comparison of these melts with natural alkaline magmas. At higher degrees of partial melting, the composition of the starting material becomes the dominant factor controlling the melt composition (Fig. 5, 6B, 6D). Thus, if the addition of $\mathrm{CO}_{2}$ to pyroxenite could modify the partial melt composition, depending on the variable composition of recycled oceanic crust and the variable amount of enclosing $\mathrm{CO}_{2}\left(\right.$ and $\left.\mathrm{H}_{2} \mathrm{O}\right)$, the addition of $\mathrm{CO}_{2}$ to pyroxenite does not seem able to solve the problem regarding the mostly constant $\mathrm{Al}_{2} \mathrm{O}_{3} / \mathrm{TiO}_{2}$ and $\mathrm{Na}_{2} \mathrm{O} / \mathrm{K}_{2} \mathrm{O}$ ratios observed in alkaline lavas (Figs. 6C, 6D).

This discussion indicates that melts produced from pyroxenites associated with the recycling of oceanic crust do not match the major-element compositions of alkaline rocks, in particular for the low- $\mathrm{SiO}_{2}$ ones. Moreover, according the large composition range observed in MORBs and oceanic gabbros in terms of $\mathrm{Al}_{2} \mathrm{O}_{3} / \mathrm{TiO}_{2}$ or $\mathrm{Na}_{2} \mathrm{O} / \mathrm{K}_{2} \mathrm{O}$ ratios, it is unlikely that the melting of recycled oceanic crust will produce melts with constant ratios. Thus, to involve oceanic crust as a major carrier of isotopically enriched compositions in the source of alkaline intraplate magmas requires a process that modifies and homogenizes the pyroxenitic melt composition before it reaches the surface. The main candidate explanations for such an homogenization process, which will be discussed in the next section, are:

(1) Assuming adiabatic upwelling, fertile lithologies such as recycled oceanic crust $\left(+\mathrm{CO}_{2}\right)$ melt at large depth and metasomatize the overlying asthenospheric mantle, followed by the melting of this enriched peridotitic mantle, possibly in the presence of $\mathrm{CO}_{2}$.

(2) Fertile lithologies $\left( \pm \mathrm{CO}_{2}\right)$ melt at depth, and the extracted melts react with surrounding peridotites before reaching the surface.

(3) Low-degree melts from the heterogeneous asthenosphere do not reach the surface, but metasomatize the lithospheric mantle, and the remelting of the resulting metasomatic veins produces the alkaline magmas observed at the surface.

\section{HYPOTHESES FOR THE GENERATION OF LOW-SILICA ALKALINE BASALT}

\section{Melting of Metasomatized Peridotite in Presence of $\mathrm{CO}_{2}$}

The first alternative above suggests that different lithologies, including recycled oceanic crust, sediments, and enriched mantle, having low solidus temperatures, melt at relatively large depths, and that the resulting liquids infiltrate and metasomatize the overlying mantle. The melting of metasomatized mantle in presence of $\mathrm{CO}_{2}$ at shallow depth produces the alkaline melts observed at the surface (Fig. 7A).

Laboratory experiments indicate that fertile lithologies such as pyroxenite or peridotite in the presence of volatiles $\left(\mathrm{H}_{2} \mathrm{O}\right.$ and/ or $\mathrm{CO}_{2}$ ) have lower solidus temperatures than volatile-free peridotite. For example, Kogiso et al. (2004) indicated that pyroxenites rich in alkalies or with low $\mathrm{Mg \#}$ will melt, at similar pressures, at temperatures of $100-200{ }^{\circ} \mathrm{C}$ lower than volatile-free peridotite. The addition of a few hundreds of parts per million of $\mathrm{H}_{2} \mathrm{O}$ and/or $\mathrm{CO}_{2}$ will also affect the melting temperature of peridotite and pyroxenite by decreasing the solidus temperature (Katz et al., 2003; Asimow et al., 2004; Dasgupta et al., 2007). As indicated previously, melts produced from recycled oceanic crust seem unable to match the major-element composition of alkaline lavas. However, this melt could interact and metasomatize the overlying mantle. The melting of metasomatized peridotite in the presence of $\mathrm{CO}_{2}$ in a later upwelling stage may produce the alkaline lavas observed at the surface (Dasgupta and Hirschmann, 2007).

Melting experiments on dry peridotite seem unable to explain the formation of low-Si alkaline lavas (Fig. 1A) (e.g., Davis et al., 2011), but the presence of $\mathrm{CO}_{2}$ significantly modifies the silica content of the melt produced by peridotite (Kushiro, 1975; Wyllie and Huang, 1976; Brey and Green, 1977; Wendlandt and Mysen, 1980; Wallace and Green, 1988; Falloon and Green, 1989; Gudfinnsson and Presnall, 2005). For example, near-solidus partial melts of peridotite in the presence of $2.5-1 \%$ wt $\% \mathrm{CO}_{2}$ are carbonatitic and evolve continuously to carbonated silicate melts with increasing temperature (Hirose, 1997; Dasgupta and Hirschmann, 2007; Foley et al., 2009). Figures 7B-7D illustrate the variable composition of carbonated low-silicate melts produced in these experiments. None of these carbonated silicate melts resemble the composition of natural nephelinite or basanite (Figs. 7B-7D). In addition, Dasgupta and Hirschmann (2007) indicate that at a given $\mathrm{MgO}$ content, the $\mathrm{CaO}$ content of these silica-poor melts is significantly higher than that observed in alkaline lavas. Two main factors could explain this discrepancy. First, the degree of partial melting at which these melts are produced $(>5 \%-10 \%$, but commonly $>15 \%)$ is significantly higher than expected for the generation of alkaline rocks by peridotite melting on the basis of trace-element constraints. Second, the $\mathrm{CO}_{2}$ added in these experiments could be more abundant than occurs in natural processes (Dasgupta and Hirschmann, 2007). Based on these considerations, Dasgupta and Hirschmann (2007) 

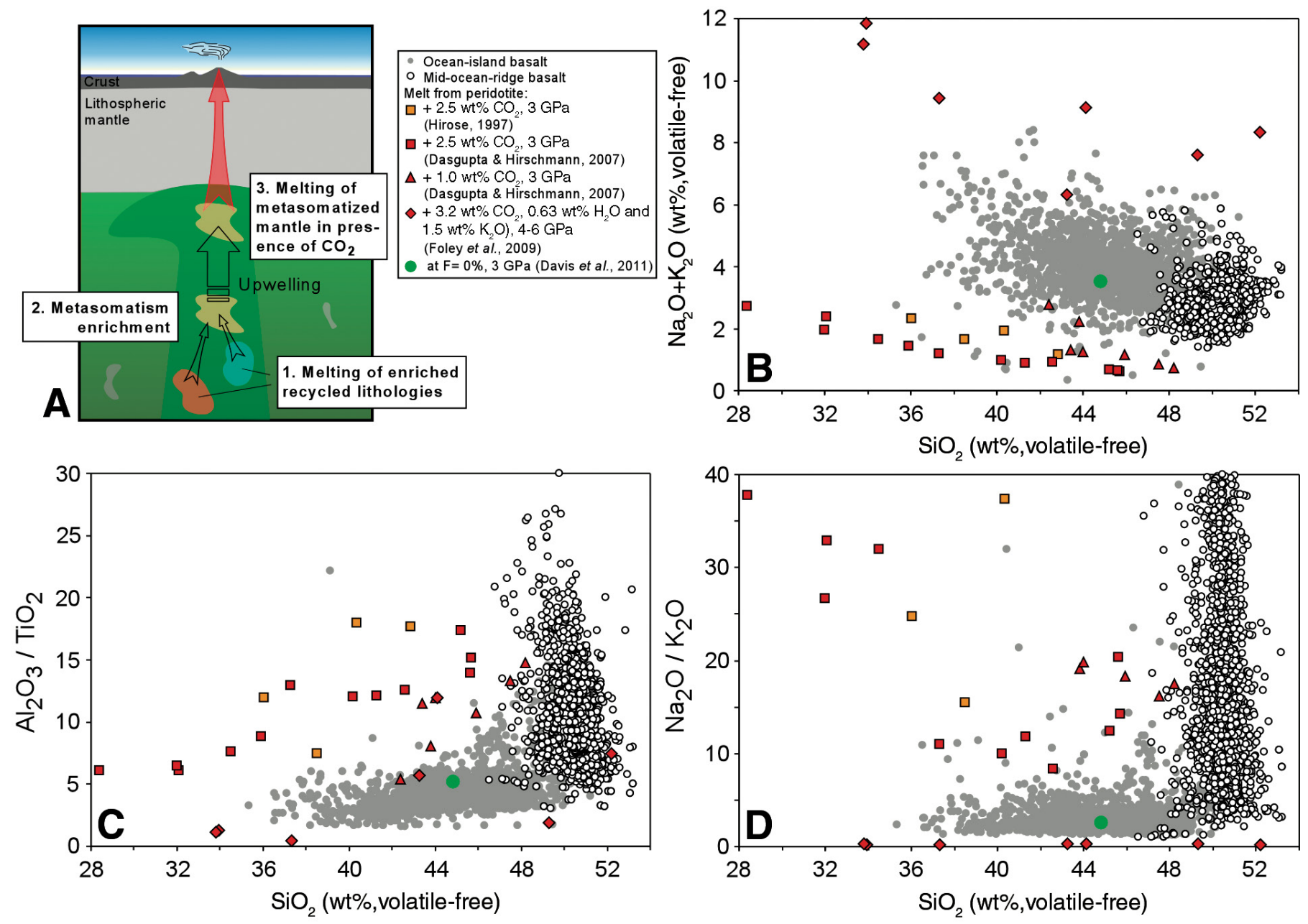

Figure 7. (A) Schematic model illustrating the generation of metasomatized peridotitic mantle considered as a potential source for alkaline lavas. (B-D) Total alkali (B), $\mathrm{Al}_{2} \mathrm{O}_{3} / \mathrm{TiO}_{2}(\mathrm{C})$, and $\mathrm{Na}_{2} \mathrm{O} / \mathrm{K}_{2} \mathrm{O}$ (D) versus $\mathrm{SiO}_{2}$ (volatile-free) diagrams for ocean-island basalts and mid-ocean-ridge basalts compared to high-pressure experimental melts produced from peridotite in the presence of $\mathrm{CO}_{2}$ (Hirose, 1997; Dasgupta and Hirschmann, 2007; Foley et al., 2009). The incipient partial melt $(F \sim 0 \%)$ of garnet peridotite at $3 \mathrm{GPa}$ from Davis et al. (2011) is given in B-D for reference.

extrapolated these results to lower $\mathrm{CO}_{2}$ contents and suggested that the major-element composition of alkaline lavas such as melilitites, nephelinites, and basanites could be produced by $\sim 1 \%-$ $5 \%$ partial melting of a fertile (metasomatized) peridotite source containing $0.1-0.25 \mathrm{wt} \% \mathrm{CO}_{2}$.

A related question is how the melting of metasomatized peridotite can satisfy the trace-element constraints illustrated in Figure 3. Any explanation for the formation of alkaline rocks from melting of metasomatized peridotite requires that the peridotite source enrichment was mostly similar below all alkaline continental and oceanic volcanoes. Based on a quantitative assessment of the trace-element budget of HIMU OIBs, Stracke et al. (2003, p. 1) noted that "Given the variability of the recycled components, a small number of relatively well-defined enriched compositions can only be explained if either the subduction processing of oceanic crust is a far better defined process than observation would seem to indicate, or the intramantle disaggregation and mixing of compositionally diverse recycled materials is surprisingly efficient." Furthermore, Willbold and Stracke (2006) estimated that $9 \%-10 \%$ of recycled oceanic crust needs to be "digested" by depleted peridotite to produce the trace-element composition suitable to comprise the source of alkaline OIBs. Which process or processes control the amount of oceanic crust added to the peridotitic mantle remains an open question.

Another question is how peridotite can be carbonated. The estimate of $\mathrm{CO}_{2}$ content for depleted MORB mantle (36 ppm; Workman and Hart, 2005) suggests that metasomatism needs to enrich the mantle by a factor $25-70$ in order to produce a peridotitic source containing the $0.1-0.25 \mathrm{wt} \% \mathrm{CO}_{2}$ inferred by Dasgupta and Hirschmann (2007). These authors suggested that peridotites are metasomatized by the addition of carbonatitic melts produced from carbon-bearing eclogite recycled at depth. Realistically, the first melts produced from such a $\mathrm{CO}_{2}$-bearing eclogite will be carbonatitic (Hammouda, 2003; Yaxley and Brey, 2004; Dasgupta 

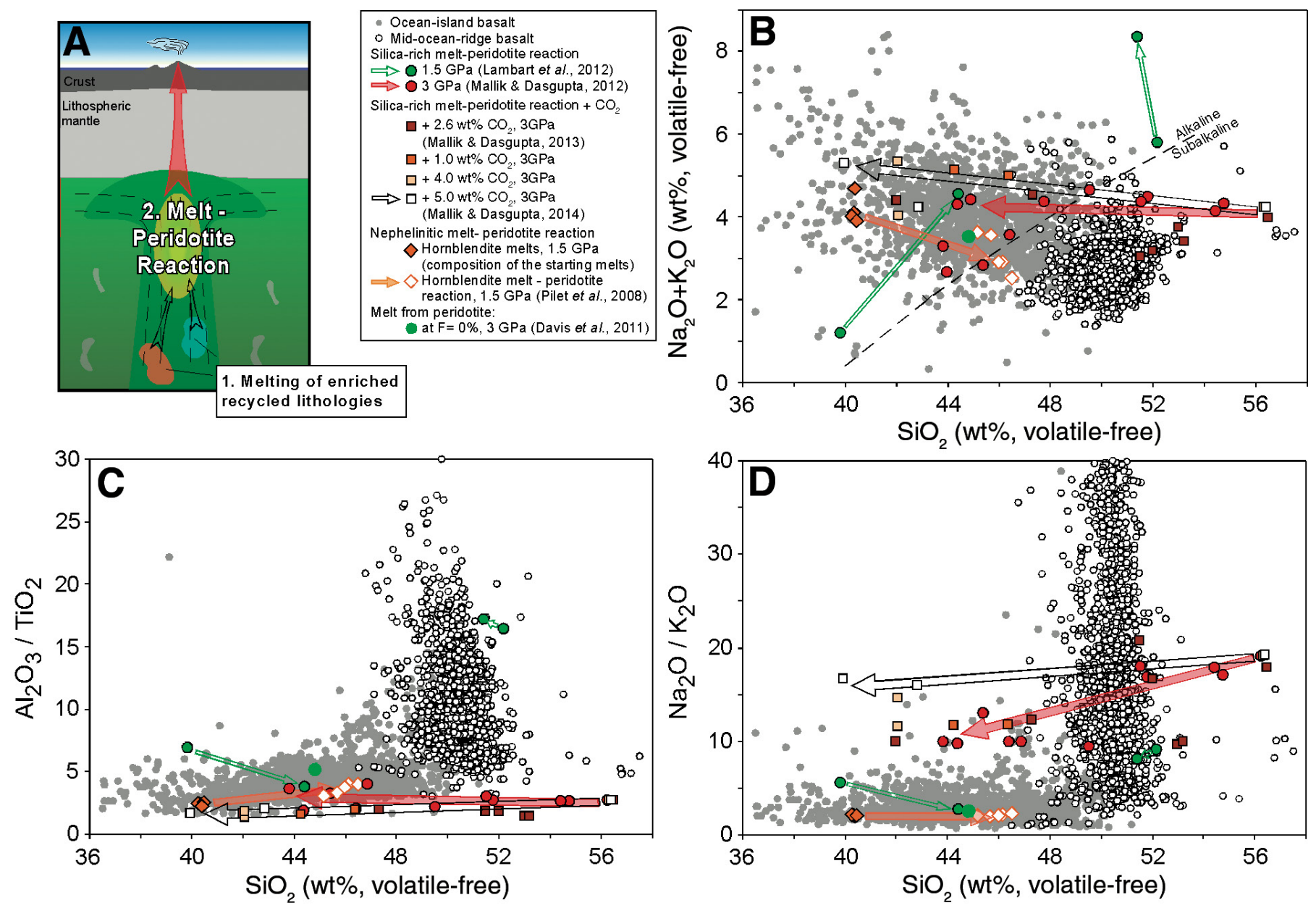

Figure 8. (A) Schematic model illustrating the generation of alkaline basalts by melt-peridotite reaction. (B-D) Total alkali (B), $\mathrm{Al}_{2} \mathrm{O}_{3} / \mathrm{TiO}_{2}(\mathrm{C})$, and $\mathrm{Na}_{2} \mathrm{O} / \mathrm{K}_{2} \mathrm{O}$ (D) versus $\mathrm{SiO}_{2}$ (volatile-free) diagrams for ocean-island basalts and mid-ocean-ridge basalts compared to experimental melts produced in silica-rich melt-peridotite reaction (dry) (Lambart et al., 2012; Mallik and Dasgupta, 2012; Yaxley and Green, 1998), in silica-rich melt-peridotite reaction in the presence of $\mathrm{CO}_{2}$ (Mallik and Dasgupta, 2013, 2014), and in silica-poor (nephelinitic) melt-peridotite reaction (Pilet et al., 2008). The arrows illustrate the reaction trends produced in these different experimental studies (the starting points shows the initial melts before the reaction). The incipient partial melt $(F \sim 0 \%)$ of garnet peridotite at $3 \mathrm{GPa}$ from Davis et al. (2011) is given in B-D for reference. The dash line in panel B distinguishes alkaline from subalkaline lavas according to Irvine and Baragar (1971).

et al., 2004; Kiseeva et al., 2012). Nevertheless, it is questionable whether these melts will have the appropriate trace-element pattern to fit the low-Si alkaline magma as seen in Figure 3. For example, Gerbode and Dasgupta (2010) and Kiseeva et al. (2012) demonstrated that in the presence of rutile coexisting with carbonatitic melts, much of the $\mathrm{Ti}$ and high field strength elements in the residue will be retained, creating negative anomalies in primitive mantle-normalized patterns. Such features are not observed in OIBs which are, on the contrary, characterized by positive $\mathrm{Nb} / \mathrm{La}$ and $\mathrm{Nb} / \mathrm{Th}$ ratios (e.g., Hofmann et al., 1986; Fig. 3).

In summary, extrapolation experiments performed at high to lower $\mathrm{CO}_{2}$ content suggest that the melting of metasomatized peridotite in presence of $\mathrm{CO}_{2}$ is a realistic candidate for explaining the major-element composition of low-Si alkaline magmas (Dasgupta and Hirschmann, 2007). However, how the source acquires the specific trace-element and $\mathrm{CO}_{2}$ content required to explain the composition of alkaline rocks worldwide remains unclear.

\section{Melt-Peridotite Reaction}

The second alternative to produce alkaline rocks suggests that the different lithologies (e.g., recycled oceanic crust, sediments, and enriched mantle) melt at depth and that these melts then react with the surrounding peridotite and are homogenized before reaching the surface (Fig. 8).

The melt-peridotite reactions produce dissolution of orthopyroxene and precipitation of olivine (or vice versa) as a function of the silica activity of the melt (Lambart et al., 2012). Clinopyroxene could also be an important reaction product and is observed in some melt-peridotite reaction experiments, but 
the factors that control its dissolution or crystallization during reaction are less well constrained. Figure 8 illustrates the different trends produced by the reaction of liquids with various silica activities with peridotite. The nephelinite $\left(+1.8\right.$ wt $\left.\% \mathrm{H}_{2} \mathrm{O}\right)$ peridotite reaction (orange arrows in Fig. 8) produces an increase in silica content in the reacting melt associated with the dissolution of orthopyroxene and precipitation of olivine until the liquid is in equilibrium with olivine-orthopyroxene-clinopyroxene and spinel (Pilet et al., 2008). In contrast, experiments using reacting melts with high silica activity will dissolve mantle olivine, leading to orthopyroxene precipitation (red arrows, Fig. 8) (Yaxley and Green, 1998; Mallik and Dasgupta, 2012). These latter experiments are the basis of a two-step model for the generation of silica-rich tholeiites proposed by Sobolev et al. (2005). In this model, silica-oversaturated melt produced at depth from recycled eclogite reacts with peridotite producing orthopyroxeneclinopyroxene-garnet pyroxenite, and the subsequent melting of this pyroxenite at shallower depth and mixing with melts there derived from the surrounding peridotite produce the silica-rich tholeiites observed at Hawaii and other large islands (Sobolev et al., 2007). All reacted melts produced in these dry or $\mathrm{H}_{2} \mathrm{O}$ undersaturated reaction experiments show compositions that approach peridotite melt in terms of silica content (Fig. 8B) but keep the specific enrichments in incompatible elements such as $\mathrm{TiO}_{2}$ or $\mathrm{K}_{2} \mathrm{O}$ of their initial reacting melts (Figs. 8C-8D). Olivine does not incorporate $\mathrm{TiO}_{2}, \mathrm{~K}_{2} \mathrm{O}, \mathrm{Al}_{2} \mathrm{O}_{3}$, or $\mathrm{Na}_{2} \mathrm{O}$ in its lattice, so its precipitation or dissolution does not affect the initial $\mathrm{Al}_{2} \mathrm{O}_{3} / \mathrm{TiO}_{2}$ or $\mathrm{Na}_{2} \mathrm{O} / \mathrm{K}_{2} \mathrm{O}$ ratios of the melts. Orthopyroxene and clinopyroxene might incorporate $\mathrm{TiO}_{2}, \mathrm{Al}_{2} \mathrm{O}_{3}$, and $\mathrm{Na}_{2} \mathrm{O}$ in small to moderate amounts, and therefore melt-rock reactions involving pyroxene precipitation or dissolution can cause variations in the $\mathrm{Al}_{2} \mathrm{O}_{3} / \mathrm{TiO}_{2}$ or $\mathrm{Na}_{2} \mathrm{O} / \mathrm{K}_{2} \mathrm{O}$ ratios. Figures $8 \mathrm{C}$ and $8 \mathrm{D}$ show the evolution of $\mathrm{Al}_{2} \mathrm{O}_{3} / \mathrm{TiO}_{2}$ and $\mathrm{Na}_{2} \mathrm{O} / \mathrm{K}_{2} \mathrm{O}$ ratios during meltperidotite reaction and indicate that if the initial ratio is too different from the ratio of the alkaline rocks, melt-peridotite reaction is unable to modify these ratios sufficiently to produce the ratios observed in alkaline sodic mafic lavas.

The addition of $\mathrm{CO}_{2}$ during melt-peridotite reaction (from 0 to $5 \mathrm{wt} \%$, Fig. 8) modifies the melt composition by slightly decreasing the $\mathrm{SiO}_{2}, \mathrm{TiO}_{2}$, and $\mathrm{Al}_{2} \mathrm{O}_{3}$ content and increasing the $\mathrm{CaO}$ content in the reacting melt (Mallik and Dasgupta, 2014). These chemical variations are linked to the variation in phase proportions coexisting with melt as a function of $\mathrm{CO}_{2}$ content. The increase in orthopyroxene content coexisting with $\mathrm{CO}_{2}$-rich melts observed by Mallik and Dasgupta (2014) is explained by the increase of the silica activity of the melt in the presence of $\mathrm{CO}_{2}$, an increase which modifies the relative proportion of orthopyroxene-olivine coexisting with the melt (where the silica activity in the melt is buffered by olivine and orthopyroxene). Based on these experimental results, Mallik and Dasgupta (2014) developed an empirical model to predict reacted melt composition as a function of reacting eclogite-derived andesite fraction and source $\mathrm{CO}_{2}$ concentration. This model suggests that low- $\mathrm{SiO}_{2}$ alkaline basalts can be produced from MORB eclogite if $\mathrm{CO}_{2}$ is pres- ent during the reaction with peridotite and if the reacted melt is then mixed with a low-degree melt from peridotite $\left( \pm \mathrm{CO}_{2}\right)$. This model is attractive because it could reconcile the composition of alkaline magma with the melting of oceanic crust. Nevertheless, several questions remain, in particular regarding the incompatible trace element (including $\mathrm{K}_{2} \mathrm{O}$ ) content of the melts before and after melt-peridotite reaction.

Various studies of the melting of a heterogeneous upwelling mantle (Hirschmann and Stolper, 1996; Phipps Morgan, 2001; Ito and Mahoney, 2005; Stolper and Asimow, 2007) indicate that the melting parameters determined for individual lithologies could vary significantly if the interaction between these lithologies is taken into account. For example, if low-solidus mafic material melts during adiabatic decompression but is chemically isolated from, but in thermal equilibrium with, enclosing peridotite, the degree of melting of this material will be enhanced relative to the amount of melting that sources composed only of this material would undergo. The enclosing peridotite will then be "refrigerated" by the melting of the mafic component, and thus will melt at lower pressure and to lower degrees than if the veins were not present (Hirschmann and Stolper, 1996; Stolper and Asimow, 2007). This point is extremely important for the melting of recycled eclogite. Ito and Mahoney (2005) have shown that, in an upwelling mantle, pyroxenite embedded in depleted peridotite is likely to melt to a large extent before reaching the base of the lithosphere. This is in contradiction with the geochemical study of Stracke et al. (2003) which indicates that the degree of partial melting at which MORB eclogite needs to melt to satisfy the trace-element composition of alkaline basalt is limited to $\sim 1 \%$. To develop their model, Mallik and Dasgupta (2014) used a fertile peridotite reacting with $\mathrm{CO}_{2}$-doped andesitic melt corresponding to $8.9 \%$ partial melting of a natural volatile-free MORB eclogite at $3 \mathrm{GPa}$ (data from Pertermann and Hirschmann, 2003a). The assumed degree of pyroxenite partial melting $(F=8.9 \%)$ is significantly lower than that predicted by thermodynamic models (Ito and Mahoney, 2005). It is unlikely that higher-degree partial melting of MORB pyroxenite could satisfy the trace-element content of alkaline lavas. For example, the maximum $\mathrm{K}_{2} \mathrm{O}$ content produced in the reaction experiments of Mallik and Dasgupta (2014) is $0.4 \mathrm{wt} \%$ (on a volatile-free basis), lower than that observed in low-Si alkaline lavas $(\sim 0.5-2 \mathrm{wt} \%)$.

Furthermore, melt derived from recycled oceanic crust is likely to be characterized by highly variable $\mathrm{Al}_{2} \mathrm{O}_{3} / \mathrm{TiO}_{2}$ or $\mathrm{Na}_{2} \mathrm{O} / \mathrm{K}_{2} \mathrm{O}$ ratios (and trace-element enrichments; Figs. 6C, 6D). Melt-peridotite reaction does not modify these ratios significantly (Figs. 8C, 8D), so it is unlikely that this could explain the formation of alkaline lavas characterized by the specific compositions observed worldwide (Figs. 3, 6A, 6B). In contrast, the model proposed by Mallik and Dasgupta (2014) suggests that the main factor needed to produce low-Si lavas is the presence of $\mathrm{CO}_{2}$ during melt-peridotite interaction. Thus, in view of the large range of composition of melts predicted for the melting of recycled lithologies (Figs. 5 and 6), the emission of low-Si alkaline lavas with variable $\mathrm{Al}_{2} \mathrm{O}_{3} / \mathrm{TiO}_{2}$ or $\mathrm{Na}_{2} \mathrm{O} / \mathrm{K}_{2} \mathrm{O}$ ratios and enrichment of 
incompatible trace elements would be expected. However, it is not observed.

In summary, as indicated by Lambart et al. (2012), meltperidotite interaction is a process fundamental to understanding the extraction of melts from the mantle. However, as regards the variability of melts produced from recycled lithologies in upwellings, this mechanism alone cannot explain the formation of alkaline lavas with specific compositions.

\section{Melting of Metasomatized Lithosphere (with and without Reaction with the Surrounding Mantle)}

In the third alternative, the melting of heterogeneous mantle produces basaltic melts with variable composition that infiltrate the base of the lithosphere. These melts do not reach the sur- face but produce metasomatic anhydrous and hydrous cumulates across the lithospheric mantle. Melting of the hydrous cumulates characterized by lower solidus temperatures produces the low-Si alkaline lavas observed at the surface (Fig. 9A).

Experimental petrology results (Pilet et al., 2008) indicate that high-degree melting of amphibole-bearing metasomatic veins followed by variable amounts of interaction with surrounding mantle can reproduce the key major- and trace-element features of alkaline magmas (Figs. 9 and 10A). Figure 9 reports experimental results from liquids obtained at $1.5 \mathrm{GPa}$ and temperatures varying from $1150{ }^{\circ} \mathrm{C}$ to $1400{ }^{\circ} \mathrm{C}$ from mostly pure natural hornblendite (sample AG4) and clinopyroxene hornblendite (sample AG7) from the French Pyrenees. The initial melts produced in both series of experiments are controlled by the incongruent melting of amphibole that creates $60 \%$ nephelinitic/basanitic melt +
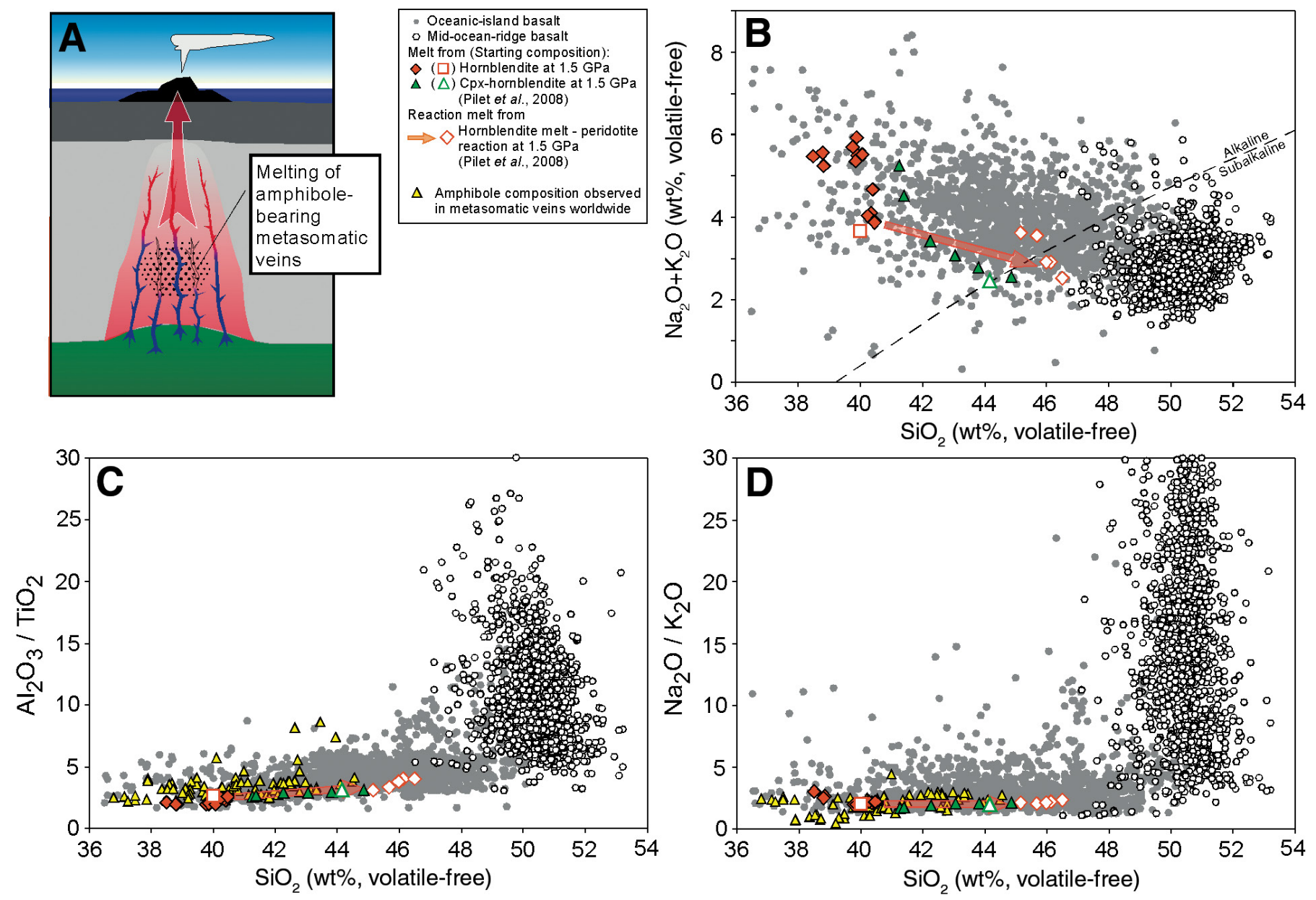

Figure 9. (A) Schematic model illustrating the generation of alkaline basalts by melting of metasomatized lithosphere. (B-D) Total alkali (B), $\mathrm{Al}_{2} \mathrm{O}_{3} / \mathrm{TiO}_{2}(\mathrm{C})$, and $\mathrm{Na}_{2} \mathrm{O} / \mathrm{K}_{2} \mathrm{O}$ (D) versus $\mathrm{SiO}_{2}$ (volatile-free) diagrams for ocean-island basalts and mid-ocean-ridge basalts compared to experimental melts produced by the melting of metasomatic amphibole-bearing veins at $1.5 \mathrm{GPa}$ (Pilet et al., 2008). Cpx-clinopyroxene. As melts from metasomatic veins are highly dependent on the composition of their enclosing amphibole, the composition of amphibole from metasomatic veins observed in oceanic and continental setting is shown in $\mathrm{C}$ and $\mathrm{D}$ (see Pilet et al. [2008] for references). The orange arrow in panels B-D connects the AG4 melt compositions to the compositions of glasses produced at same temperature $\left(1300^{\circ} \mathrm{C}\right)$ in the sandwich experiments (AG4 + peridotite) and illustrates how melt compositions change with the assimilation of orthopyroxene (+ spinel) from the peridotite layers. The dashed line in panel B distinguishes alkaline from subalkaline lavas according Irvine and Baragar (1971). 

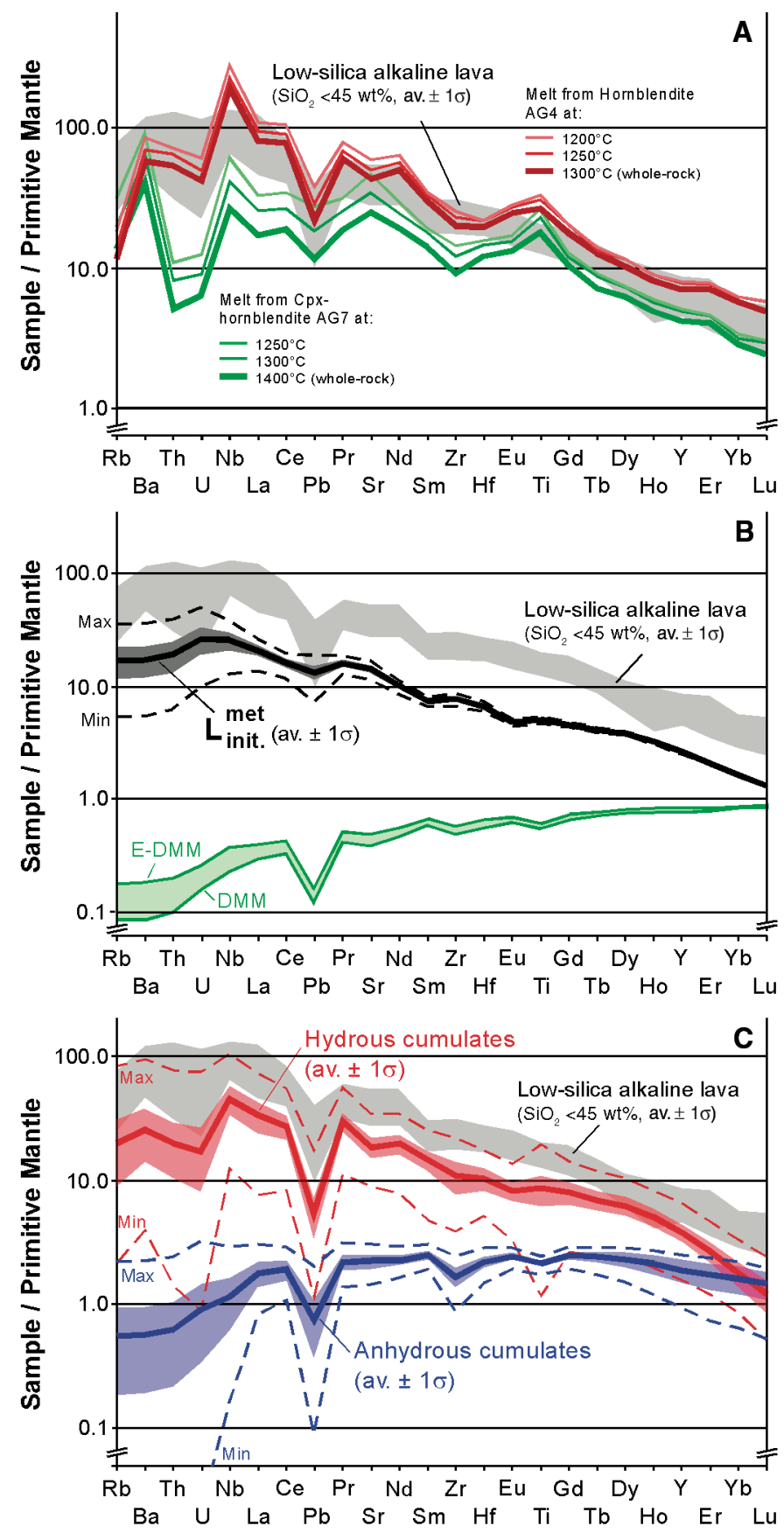

$30 \%$ clinopyroxene $+10 \%$ olivine and spinel (Pilet et al., 2008). This melting behavior explains why the melts produced for both starting materials at $1250^{\circ} \mathrm{C}$ (first melt composition reported for clinopyroxene hornblendite, AG7 experiment) are mostly similar (Fig. 9). Only at a temperature higher than $\sim 1275^{\circ} \mathrm{C}$ (at $1.5 \mathrm{GPa}$ ) does the amount of clinopyroxene in the starting material start to be important. These experiments suggest that the main factor that explains the formation of nephelinite/basanite melts is the presence of amphibole, and that any metasomatic vein containing amphibole can produce low-Si alkaline melts.
Figure 10. (A) Primitive mantle-normalized trace-element abundances for hornblendite (AG4) and clinopyroxene hornblendite (AG7) melts produced in melting experiments at $1.5 \mathrm{GPa}$ (Pilet et al., 2008). (B-C) Primitive mantle-normalized main results of the Monte Carlo simulation of metasomatism enrichment in the lithosphere (Pilet et al., 2011). In these simulations, low-degree melts $\left(\mathrm{L}^{\mathrm{met}}{ }_{\text {init }}\right.$, in $\left.\mathrm{B}\right)$ produced from the melting of a DMM to E-DMM source (green band in B) do not produce basaltic melt at the surface, but percolate and differentiate across the lithospheric mantle, producing first anhydrous cumulates (clinopyroxene + garnet and/or olivine, blue band in C) and then hydrous cumulates (amphibole + clinopyroxene + accessory minerals, red band in $\mathrm{C}$ ) (see Pilet et al. [2011] for details of the calculation). The gray band in all panels shows the range (defined as $\pm 1 \sigma$ of the average) of trace-element contents in low silica ocean-island basalt lavas (40-45 wt\% $\mathrm{SiO}_{2}$ ) with 8-15 wt\% MgO. Cpx-clinopyroxene.

Figure 10A illustrates the trace-element composition of the hornblendite ( \pm clinopyroxene) melts which show a high degree of trace-element enrichment associated with LREE/ HREE fractionation resembling the oceanic nephelinites and basanites (see Pilet et al. [2008] for details). These experiments demonstrate therefore that low-Si alkaline melts can be produced from a relatively high degree of melting of amphibolebearing metasomatic veins present within the lithosphere. This is the major difference from other models for the generation of alkaline lavas. In this model, alkaline rocks are produced by large degrees of melting of small volumes of trace element- and volatile-rich material rather than by low degrees of melting of less-enriched material as is commonly assumed. However, the incompatible trace-element composition of melts produced at high degrees of partial melting (more than a few tenths of a percent) mostly reflects the composition of their sources. So an important question related to this model is how these metasomatic veins are formed given that some diagnostic features of alkaline magmas observed worldwide are simply inherited from their metasomatic source lithologies.

\section{Metasomatic Enrichment in the Lithosphere}

Metasomatic enrichment in the lithosphere is observed via the presence of cumulates (metasomatic veins) associated with cryptic and modal metasomatism in peridotite. This is interpreted as the percolation and differentiation of low-degree volatile-rich melts within the lithosphere (e.g., Bodinier et al., 1987; Nielson and Noller, 1987; Wilshire, 1987; Nielson and Wilshire, 1993; Harte et al., 1993). The high content of incompatible trace elements observed in metasomatic veins has suggested that the low-degree melts that produce these veins are similar to alkaline magmas (e.g., Bodinier et al., 1987). However, fractional crystallization experiments performed at lithospheric mantle pressure (0.93-1.5 GPa) starting from an initial CIPW nepheline-normative liquid (Pilet et al., 2010) and a CIPW orthopyroxene-normative one (Nekvasil et al., 2004) demonstrate that the amphibole-bearing cumulates similar to hydrous metasomatic veins could be produced by differentiation 
of any basaltic melt, no matter if this melt is alkalic or subalkalic. The only constraint is that the basaltic melt needs to contain $\sim 1 \mathrm{wt} \% \mathrm{H}_{2} \mathrm{O}$, which is likely for melt produced at a low degree of partial melting from the asthenospheric mantle. Figure 11 shows that the composition of amphibole crystallizing in these two series of fractional crystallization experiments (Nekvasil et al., 2004; Pilet et al., 2010) is similar to that of amphibole observed in metasomatic veins worldwide. The similarity of amphibole composition crystallizing from initial orthopyroxene- or nepheline-normative liquids indicates that the mineralogical structure of the amphibole is more important from the point of view of controlling its major-element composition than the composition of the melts from which amphibole crystallized (Pilet et al., 2010). This is particularly well expressed by the $\mathrm{Al}_{2} \mathrm{O}_{3} / \mathrm{TiO}_{2}$ ratio of the amphiboles, which is mostly constant (from 2.5 to 4, Fig. 11C) even while the ratios in the melts from which amphiboles crystallized vary significantly (from 3 to 40). Figure 11 demonstrates also the perfect match between the amphibole observed in metasomatic veins and the composition of low-Si alkaline lavas, illustrating a fundamental aspect of the metasomatic hypothesis: the formation of amphibole cumulates suitable to be a source for low-Si alkaline lavas in term of major elements could be explained by the percolation of any type of low-degree melts from the asthenosphere (i.e., it does not matter if the initial liquid is nepheline or orthopyroxene normative; Fig. 11).

\section{Monte Carlo Simulation for Metasomatic Enrichment in the Lithosphere}

To evaluate the type of mantle source required to produce amphibole cumulates as rich in incompatible trace elements as observed in natural metasomatic veins from the French Pyrenees (whole-rock AG4 and AG7 in Fig. 10A), Pilet et al. (2011) performed Monte Carlo simulations of the metasomatic enrichment in the lithosphere starting from low-degree melt from sources similar to depleted MORB mantle (DMM). The use of Monte Carlo simulation allowed propagation of the uncertainty of the different parameters that control the formation of the metasomatic veins. These include the source composition (varying from DMM to E-DMM), the degree of partial melting ( $F$ varying from $0.5 \%$ to $1.7 \%$ ), and the proportion of phases including accessory minerals that crystallized during the percolation and differentiation process. This model is constrained by experiments and the mineral compositions and modes observed in metasomatic veins (Pilet et al., 2011). It assumes that migration, cooling, and fractional crystallization of the metasomatic melts within the lithospheric mantle generate a continuum of phase assemblages from anhydrous (clinopyroxene + garnet \pm olivine) to hydrous (clinopyroxene + amphibole \pm phlogopite) veins plus cryptic enrichment in the surrounding peridotite. The main conclusion of these simulations is that the compositions of the hydrous cumulates calculated are highly enriched in incompatible trace elements and their patterns share many similarities with the patterns of alkaline
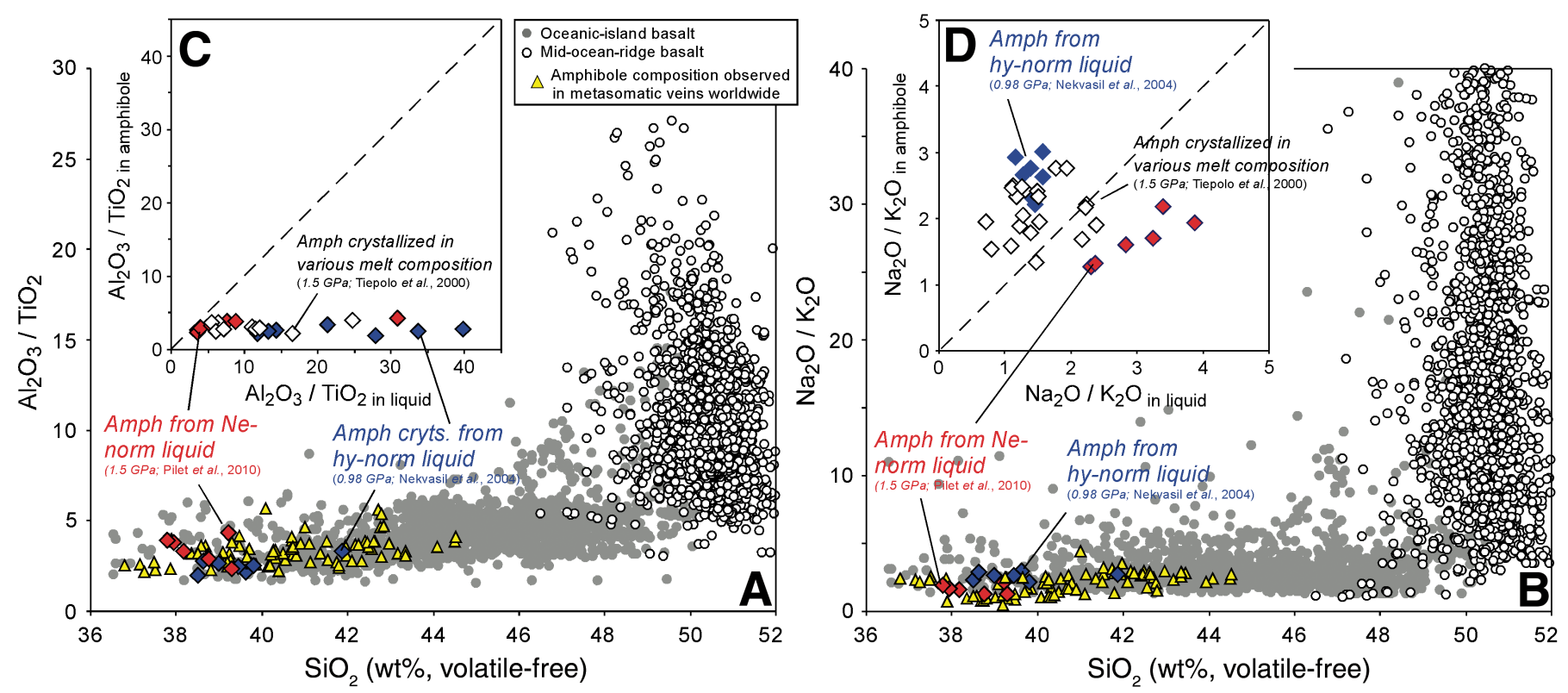

Figure 11. (A-B) $\mathrm{Al}_{2} \mathrm{O}_{3} / \mathrm{TiO}_{2}$ versus $\mathrm{SiO}_{2}$ (volatile-free) (A) and $\mathrm{Na}_{2} \mathrm{O} / \mathrm{K}_{2} \mathrm{O}$ versus $\mathrm{SiO}_{2}$ (volatile-free) (B) diagrams for ocean-island basalts and mid-ocean-ridge basalts compared to the composition of amphibole from oceanic and continental metasomatic veins (yellow triangles; see Pilet et al. [2008] for references) and amphibole crystallizing in fractional crystallization experiments at lithospheric pressure starting from distinct initial melts (silica-saturated melts from Nekvasil et al. [2004] and silica-undersaturated melts from Pilet et al. [2010]). (C-D) Comparison of $\mathrm{Al}_{2} \mathrm{O}_{3} / \mathrm{TiO}_{2}$ and $\mathrm{Na}_{2} \mathrm{O} / \mathrm{K}_{2} \mathrm{O}$ ratios in amphibole versus coexisting liquids in different crystallization experiments (Tiepolo et al., 2000; Nekvasil et al., 2004; Pilet et al., 2010). Amph—amphibole; Ne-norm—nepheline-normative; hy-norm—hyperstene-normative. 
OIBs (positive $\mathrm{Nb} / \mathrm{La}$, negative $\mathrm{Ce} / \mathrm{Pb}$, same LREE/HREE fractionation; Fig. 10C). These simulations also show that the source of these crystallizing melts does not need to be extremely enriched in incompatible trace elements, but could correspond to DMM. This study demonstrated that the differentiation of low-degree melts from a MORB mantle source (Fig. 10B) can produce amphibole-bearing cumulates suitable to be a source of alkaline lavas in terms of trace-element compositions (Pilet et al., 2011; Fig. 10C).

The combination of experimental data on the differentiation of basaltic melts across the lithosphere with the Monte Carlo simulation supports the model suggested for the formation of alkaline lavas in the Cantal massif (Central Massif, France; Pilet et al., 2004). This three-step model needs to be viewed in a dynamic way:

(1) The heterogeneous asthenospheric mantle melts at low degrees, producing initial metasomatic melts (Fig. 12A).

(2) These melts percolate and differentiate along the thermal gradient in the lithosphere and produce metasomatic cumulates with major- and trace-element compositions suitable for a source of low-silica alkaline lavas (Fig. $12 \mathrm{~B})$. The progressive addition of metasomatic veins modifies the thermal gradient of the lithospheric mantle.
At some point, the rise in temperature is sufficient to remobilize the amphibole veins characterized by low solidus temperature $\left(\sim 1150-1175{ }^{\circ} \mathrm{C}\right.$ from 1.5 to $\left.2.5 \mathrm{GPa}\right)$ precipitated at an early stage (Figs. 12B-12C).

(3) The remelting of the amphibole-bearing veins produces low-silica alkaline magmas, while melt-peridotite reaction explains the compositional continuum observed in alkaline volcanoes (Fig. 12C).

The implication of amphibole in the source of intraplate magmas has been proposed by various authors (e.g., Class and Goldstein, 1997; Jung et al., 2005; Panter et al., 2006; Ma et al., 2011; Adam and Green, 2011; Rooney et al., 2014) in order to explain the $\mathrm{Rb}, \mathrm{Ba}$, and $\mathrm{K}$ content of alkaline lavas, but the detail of the proposed models may differ from the model suggested here. The strength of the metasomatized lithosphere model is that the formation of amphibole cumulates is independent of the process responsible for generation of the initial metasomatic melts at the base of the lithosphere. Various processes such as mantle upwelling linked to mantle convection, shallow tectonic process creating lithosphere thinning, or delamination of the base of the crust are able to generate low-degree melts at the base of the lithosphere, which, by percolation and differentiation, may produce amphibole-rich cumulate suitable to be the source of alkaline

\section{Low-silicate alkaline basalts}

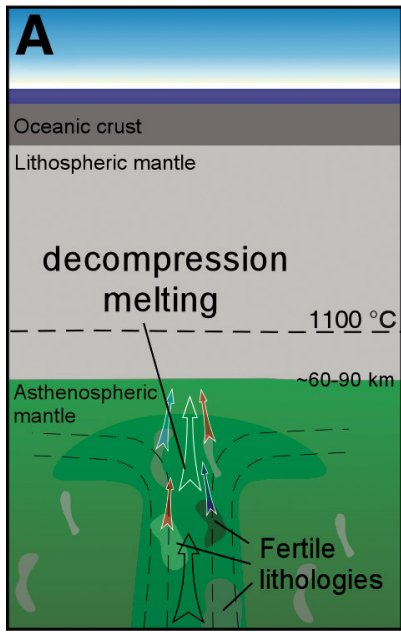

Stage 1: generation of low degree melts in the asthenosphere

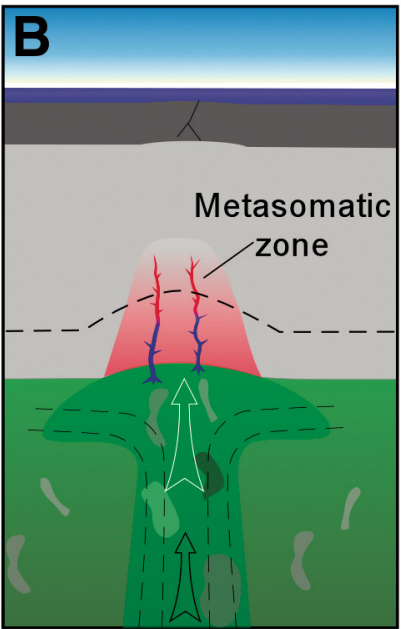

Stage 2: percolation and differentiation of the metasomatic melts

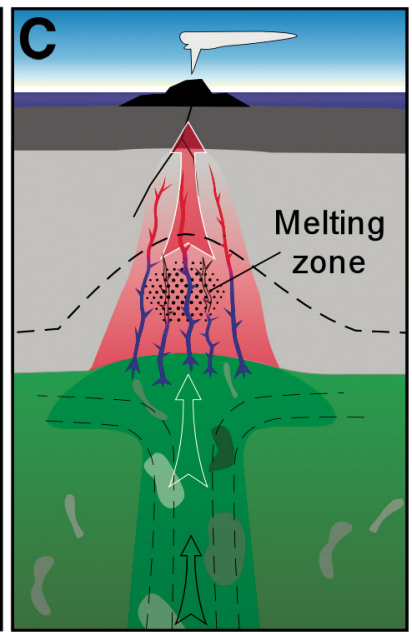

Stage 3: melting of metasomatic veins and generation of alkaline basalts

low asthenospheric melt production - thick lithosphere

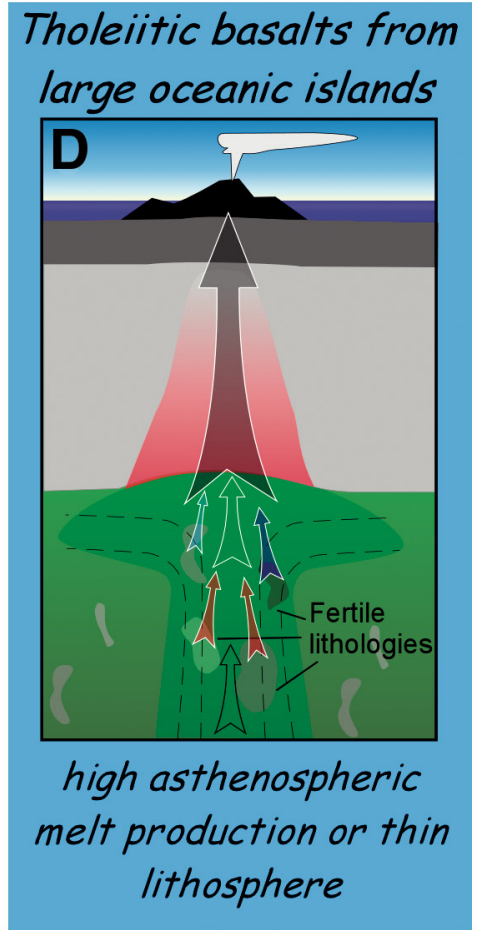

Figure 12. (A-C) Schematic models for the generation of alkaline lavas by the melting of metasomatic lithosphere. (A) The heterogeneous asthenospheric mantle melts to a low degree and produces initial metasomatic agents. (B) These melts percolate and differentiate along the thermal gradient in the lithosphere and produce metasomatic cumulates. The process is associated with the rise of the lithosphere thermal gradient. (C) When the temperature is sufficient $\left(1150-1175^{\circ} \mathrm{C}\right)$, amphibole-bearing cumulates melt and produce low-silica alkaline lavas such as nephelinites or basanites. The compositional continuum observed in alkaline volcanoes is explained by various degrees of meltperidotite reaction. (D) The model shown in A-C is realistic only at low asthenospheric melt production rates. If this production is too high, asthenospheric melts reach the surface directly and produce the tholeiites observed in large oceanic islands such as Hawaii or La Réunion. 
magmas. This provides an explanation of why alkaline magmas are so similar in different tectonic contexts (e.g., intracontinental, intraoceanic, continental rifting). The metasomatized lithosphere hypothesis is also in agreement with the potential origin of intraplate magma from the LLAMA model (laminated lithologies and aligned melt arrays; Anderson, 2011; Anderson and Natland, 2014). This zone is inferred from high-resolution seismic body waves recorded at the base of the lithosphere (Kawakatsu et al., 2009) to contain fertile, metasomatic, enriched, depleted, refractory, and ancient components which are segregated into lamellae by shear rather than chaotically stirred into a marble cake. Low-degree melts extracted from this zone are ideal candidates to produce enriched metasomatic veins suitable for the source of low-Si alkaline lavas.

Nevertheless, several aspects of the metasomatized lithosphere hypothesis for the origin of alkaline magmas require further study. First, the generation of isotopic heterogeneities observed in alkaline lavas requires long-term isolation of components characterized by variable trace-element ratios (e.g., Rb/ $\mathrm{Sr}, \mathrm{Sm} / \mathrm{Nd}, \mathrm{Lu} / \mathrm{Hf}, \mathrm{U} / \mathrm{Pb}$ ), while the dynamic model illustrated in Figure 12 implies a short-term process. We suggest that the isotopic variations observed in alkaline lavas worldwide are not linked to the metasomatic process itself, but to the heterogeneous nature of the convecting mantle. The isotopic composition of the underlying asthenosphere will control the isotopic composition of the alkaline lavas, while the major- and trace-element content is controlled by the petrological process responsible for the formation of metasomatic veins. The metasomatized lithosphere hypothesis is therefore not at odds with isotopic studies on OIBs which demonstrate that the mantle is heterogeneous. On the contrary, this model could solve the problem that components such as recycled oceanic crust, recycled sediments, and delaminated continental crust are unlikely to be the source lithologies of the alkaline lavas by transfering the isotopic signature of these recycled lithologies to the metasomatized lithospheric source.

The metasomatized lithosphere model suggests that alkaline rocks could be produced by large degrees of melting of small volumes of trace element- and volatile-rich material. An important question is related to the volume of metasomatic veins required to produce the alkaline magmas observed at the surface. Melting experiments on hornblendite (Pilet et al., 2008) show that it is not the proportion of the hydrous veins that is important, but the proportion of amphibole. Melting experiments on amphibolebearing veins indicate that amphibole breakdown will create $60 \%$ low-Si alkaline liquid $+30 \%$ clinopyroxene $+10 \%$ olivine and spinel (at 1.5 GPa; Pilet et al., 2008). Thus, the mass of amphibole that needs to be present at depth is required to be about twice the mass of erupted lavas. Amphibole is a major crystallizing phase during the percolation and differentiation of low-degree melts across the lithosphere (Nekvasil et al., 2004; Pilet et al., 2010). Nekvasil et al. (2004) and Pilet et al. (2010) demonstrated that one-third to one-half of the initial melt is converted to amphibole. As a consequence, for every $1 \mathrm{~km}^{3}$ of asthenospheric melts that percolates and differentiates across the lithosphere, $0.3-0.5 \mathrm{~km}^{3}$ of amphibole will be created associated with the production of $0.5-0.7 \mathrm{~km}^{3}$ of anhydrous cumulates such as pyroxenite. Assuming that all the amphibole melts and that $60 \%$ of the amphibole is converted to alkaline melts, it would create $0.18-0.3 \mathrm{~km}^{3}$ of alkaline magmas. It is interesting to note that the volume proportion of extrusive versus intrusive magmas estimated in this model ( 0.2-0.4) is similar to the estimate by Schmincke (2004) for extrusive versus intrusive magma emitted by intraplate volcanism globally $\left(0.4 \mathrm{~km}^{3}\right.$ of extrusives for every $2 \mathrm{~km}^{3}$ of intrusive magmas; Schmincke, 2004).

A third question is the mechanism by which amphibolebearing metasomatic cumulates melt. As suggested by Pilet et al. (2004) and illustrated in Figure 12, the melting of metasomatic veins is explained by the migration of the thermal front associated with progressive metasomatism of the lithosphere. This model is based on the process of thermal erosion of the lithosphere observed, for example, in the Ronda peridotitic massif (southern Spain; Van der Wal and Bodinier, 1996; Bodinier et al., 2008) or in eastern Central Alps ophiolites (Müntener et al., 2010). Nevertheless, the physical aspect of the metasomatic model remains poorly constrained, and physical modeling is required to evaluate if this mechanism is realistic or not.

\section{THERMAL IMPLICATION OF THE DIFFERENT HYPOTHESIS FOR THE FORMATION OF THE LOW-SILICA ALKALINE BASALTS}

Various petrological studies have used tholeiitic basalts sampled at mid-ocean ridges and oceanic islands to constrain the thermal state of the convecting mantle and the potential mantle temperature at which basalt from ocean islands or LIPs are formed (Asimow et al., 2001; Green et al., 2001; Herzberg and O’Hara, 1998; Kinzler and Grove, 1992; Putirka, 2005; Putirka et al., 2007). These studies are based on experimental constraints showing that $\mathrm{MgO}$ and $\mathrm{FeO}$ content in basalt vary as a function of melting temperature of dry peridotite. Based on the assumption that tholeiites are produced by melting of peridotite, most studies conclude that tholeiites observed in large ocean islands and LIPs are produced at higher temperature that MORBs. Nevertheless, some authors disagree with the method used to estimate the composition of primitive magma and, by extension, the melting temperatures calculated (e.g., Presnall and Gudfinnsson, 2011). In contrast to tholeiitic magmas, the temperature at which alkaline basalts are produced is not well constrained. For example, Herzberg and Gazel (2009) constrained the melting temperature and extent of melting for LIPs and ocean islands. However, they excluded all low-Si alkaline lavas assuming that these rocks are produced by $\mathrm{CO}_{2}$-rich sources.

The lack of consensus regarding the thermal regime in which alkaline rocks are produced can be understood if the different hypotheses suggested for the origin of these rocks are considered. In this section we will evaluate qualitatively the thermal implications of the three hypotheses discussed in this paper for the origin of alkaline rocks, i.e., (1) melting of metasomatized peridotite in 
the presence of $\mathrm{CO}_{2}$, (2) melt-peridotite reaction, and (3) melting of metasomatized lithospheric veins.

Figure 13 shows the solidi of various materials potentially present in the upwelling mantle feeding oceanic or continental intraplate volcanoes. This figure illustrates that, assuming realistic potential adiabatic temperatures from $1320{ }^{\circ} \mathrm{C}$ to $1550{ }^{\circ} \mathrm{C}$, any fertile lithology (i.e., pyroxenite $\pm \mathrm{CO}_{2} / \mathrm{H}_{2} \mathrm{O}$, volatile-bearing peridotite) embedded in an upwelling mantle melts to some extent before reaching the base of thick, old oceanic lithosphere. Melting of depleted MORB mantle (indicated by the solidus for dry anhydrous peridotite in Fig. 13) is limited beneath old oceanic lithosphere and will occur only if $T_{\mathrm{p}}$ is high. This provides a maximum temperature for the generation of low-Si alkaline lavas. This is because any melts produced from fertile litholo-

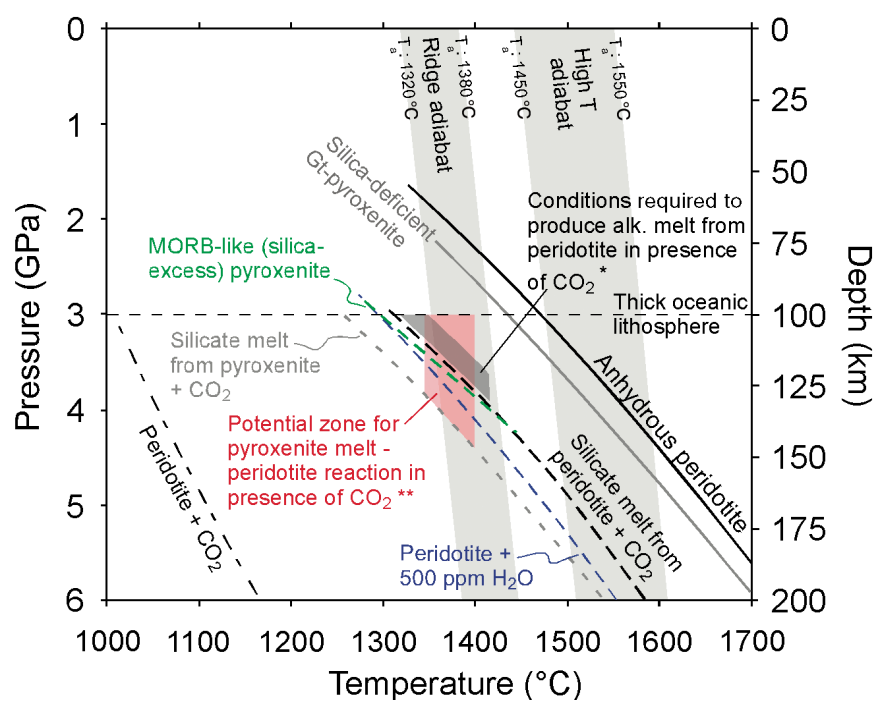

Figure 13. Pressure-temperature $(P-T)$ diagram showing locations of the solidi of various lithologies potentially present in a heterogeneous mantle: peridotite in the presence of $\mathrm{CO}_{2}$ (black long-short dashed line; Dasgupta and Hirschmann, 2006, 2007), silica-deficient garnet (Gt) pyroxenite (gray solid line; Hirschmann et al., 2003; Kogiso et al., 2003; Keshav et al., 2004), anhydrous peridotitic mantle (black solid line; Hirschmann, 2000), hydrous peridotite calculated assuming a $\mathrm{H}_{2} \mathrm{O}$ content of 500 ppm (blue dashed line; Katz et al., 2003), and mid-ocean-ridge basalt (MORB)-like pyroxenite (green dashed line; silica-excess pyroxenite; Pertermann and Hirschmann, 2003b). The condition for the generation of silicate-carbonated melts from peridotite and pyroxenite in the presence of $\mathrm{CO}_{2}$ (black and gray dashed lines; Dasgupta and Hirschmann, 2007) are also shown for reference. The gray bands represent geotherms for a mantle potential temperature of $1320-1380^{\circ} \mathrm{C}$ (corresponding to a mid-ocean adiabat path; adiabat gradient of $10{ }^{\circ} \mathrm{C} / \mathrm{GPa}$ ) and for a high mantle potential temperature $\left(1450-1550{ }^{\circ} \mathrm{C}\right)$ similar to estimates for mantle plumes. * $-P-T$ conditions for the generation of alkaline (alk.) melts from peridotite in the presence of $\mathrm{CO}_{2}$ are estimated using a $\mathrm{CO}_{2}$ content in peridotite of $0.25 \mathrm{wt} \%$ and degree of partial melting from $1 \%$ to $5 \%$ (according to Dasgupta and Hirschmann [2007]) and parameterization of the effect of $\mathrm{CO}_{2}$ on melting temperature from Dasgupta et al. (2007). **_ $P-T$ condition suggested by Mallik and Dasgupta (2014) for the generation of alkaline lavas via pyroxenite melt-peridotite reaction in the presence of $\mathrm{CO}_{2}$. gies, $\mathrm{CO}_{2}$-rich lithologies, or pyroxenites representing a potential asthenospheric source for alkaline basalts would be mixed with more abundant tholeiitic melts produced from the depleted MORB mantle if the enclosing mantle reached its solidus.

Figure 13 shows the pressure-temperature conditions estimated by Dasgupta and Hirschmann (2007) for the generation of alkali basalt via the melting of metasomatized peridotite in the presence of $\mathrm{CO}_{2}$. These conditions, in particular for the lowSi nephelinites or basanites that require low degrees of partial melting (1\%-5\%; Dasgupta and Hirschmann, 2007), suggest a $T_{\mathrm{p}}$ in the lower range of MORBs. Mantle characterized by higher $T_{\mathrm{p}}$ will begin melting of $\mathrm{CO}_{2}$-rich rock deeper and allow this mantle to melt to higher extents before reaching the base of the lithosphere.

Melt-peridotite reaction is expected to occur at any temperature or pressure. Thus, the condition for the generation of alkaline rocks via infiltration and melt-peridotite interaction is strongly dependent on the conditions of melting of the fertile lithologies generating the reacting melt. This is more important than the pressure-temperature conditions of the reaction itself. In order to explain the high trace-element contents of alkaline rocks, the degree of partial melting of the fertile lithologies must be low. Considering the low solidi of recycled lithologies (Fig. 13), $T_{\mathrm{p}}$ is forced to be close to MORB values. Nevertheless, as indicated before, the high fertility of pyroxenite (i.e., high $\delta F / \delta P$, in $\mathrm{GPa}^{-1}$; Ito and Mahoney, 2005) makes it difficult to limit the extent of melting of such material to low degrees.

In the metasomatized lithosphere hypothesis, the melting of fertile lithologies from asthenospheric mantle is not related to the generation of alkaline lavas, but to the generation of the metasomatic agent which produces the metasomatic veins by percolative fractional crystallization. The model for the formation of metasomatic veins constrains the potential temperature required for the generation of metasomatic veins suitable to be a source of alkaline lavas. Low-degree melts $(F=0.5 \%-1.5 \%)$ from a source similar to depleted MORB mantle is sufficiently enriched in trace elements to produce such metasomatic veins (Pilet et al., 2011) and requires $T_{\mathrm{p}}$ around $1350-1380^{\circ} \mathrm{C}$ if the peridotites are slightly enriched in volatiles $\left(500 \mathrm{ppm}\right.$ of $\mathrm{H}_{2} \mathrm{O}$ and $150 \mathrm{ppm}$ of $\mathrm{CO}_{2}$ ). This temperature will also be sufficient to partially melt other fertile lithologies such as pyroxenites potentially present in a heterogeneous asthenosphere. Mantle regions characterized by higher $T_{\mathrm{p}}$ will produce higher amounts of asthenospheric melt, limiting the lithospheric filter role (i.e., the melts will reach the surface without producing the metasomatic enrichment required to explain the chemical composition of alkaline magmas; Fig. 12D).

In summary, all the models for the origin of low-Si alkaline mafic magmas require low $T_{\mathrm{p}}$ to limit the degrees of partial melting of the heterogeneous mantle. This suggests that the formation of nephelinite or basanite is at odds with the presence of thermal anomalies. A similar conclusion has been reached by Herzberg and Gazel (2009) and Lustrino (2011) using different approaches. However, in order to exclude hot mantle plumes 
in such environments it is necessary to discuss the processes responsible for the continuum from nephelinite to alkali basalt and sometimes tholeiite observed in many alkaline volcanoes. In particular the generation of alkali basalt-tholeiite associations could potentially imply higher melting temperatures than hypothesized for nephelinites.

\section{POTENTIAL ORIGIN OF THE CONTINUUM NEPHELINITE-BASANITE-ALKALI BASALT-THOLEIITE}

The compositional continuum in terms of $\mathrm{SiO}_{2}$ and alkalis from nephelinites and basanites to alkali olivine basalts and sometimes tholeiites (Fig. 1) is observed in many intraplate volcanoes (Caroff et al., 1997; Wilson et al., 1995; Lustrino et al., 2002). The trace-element patterns and isotopic composition are generally similar for the various basic magmas from a single province, but with overall trace-element concentrations decreasing with decreasing alkalinity (i.e., as magmas become less nepheline normative and reach orthopyroxene-normative compositions). The general decrease in incompatible traceelement concentrations without substantial complementary change in isotope composition or trace-element ratios from nephelinites and basanites to alkali olivine basalts and tholeiites has been interpreted as an increase in the degree of partial melting of a common source (Wilson et al., 1995; Caroff et al., 1997; Lustrino et al., 2002). Lustrino et al. (2002) suggested that the degree of partial melting increases from $4 \%-6 \%$ for the generation of alkaline lavas to $10 \%-15 \%$ for tholeiites in Sardinia (Italy), while Caroff et al. (1997) reported smaller ranges for an alkaline suite in Tubaii (Austral Islands, French Polynesia) $(1.5 \%-3 \%$ for nephelinites versus $5 \%-8 \%$ for alkali olivine basalts).

Experimental studies have shown that an increase of melt fraction for dry peridotite or MORB pyroxenite from 5\% to $15 \%$ at constant pressure implies an increase in temperature of a maximum of $50-80{ }^{\circ} \mathrm{C}$ (Pertermann and Hirschmann, 2003b; Walter, 1998; Wasylenki et al., 2003). A lower estimate for the temperature increase is provided by Hirschmann et al. (1998) that indicates an increase of $0.45 \%$ in the degree of partial melting of fertile peridotite for each degree of temperature increase. The temperature change required to increase the degree of partial melting from $2 \%$ to $8 \%$ for a peridotite source slightly increases as a function of the amount of $\mathrm{CO}_{2}$ added (Dasgupta et al., 2007). Nevertheless, the temperature to produce $8 \%$ melts from a peridotite containing $1000 \mathrm{ppm}$ of $\mathrm{CO}_{2}$ at $3 \mathrm{GPa}$ is still low ( 1480-1490 ${ }^{\circ} \mathrm{C}$; Dasgupta et al., 2007). These constraints suggest that the formation of lavas of nephelinite and basanite to alkali basalt and tholeiite composition from a common source is not associated with significant thermal variations in the upwelling mantle. Taking into account that nephelinite generation requires low $T_{\mathrm{p}}$, the difference required to generate more tholeiitic lavas does not imply significantly different temperature $\left(+50-80{ }^{\circ} \mathrm{C}\right.$ maximum).
Pilet et al. (2008) called into question the interpretation of the alkaline series continuum as a simple increase in the degree of partial melting of a common source. The major problem with this interpretation is that no experiments on mantle lithologies (peridotite, pyroxenite) have reproduced the observed compositional spectrum or the observed range of silica contents, which is $~ 40-48 \mathrm{wt} \% \mathrm{SiO}_{2}$ (Figs. 1A and 5; Hirose and Kushiro, 1993; Walter, 1998; Hirschmann et al., 2003; Pertermann and Hirschmann, 2003a; Kogiso et al., 2003; Wasylenki et al., 2003; Keshav et al., 2004; Kogiso and Hirschmann, 2006; Dasgupta and Hirschmann, 2007). For example, Hirschmann et al. (1998) showed that the progressive melting of peridotite is associated first with a decrease in silica for melt fractions of $0 \%-5 \%$ followed by a nearly constant $\mathrm{SiO}_{2}$ content from $5 \%$ to $15 \%$ melting. Alternatively, the compositional continuum from nephelinite and basanite to alkali basalt and tholeiite has been interpreted as a reaction between nephelinitic and/or basanitic liquid and surrounding peridotite (Lundstrom et al., 2000; Pilet et al., 2008). The interpretation of this continuum as a reaction between an alkaline magma and peridotite is supported by sandwich experiments where alkaline melts produced by hornblendites react with peridotite (Pilet et al., 2008). Figures 8 and 9 show that the melts produced by the reaction are significantly richer in $\mathrm{SiO}_{2}$ ( $4-5 \mathrm{wt} \%$ more) than the initial alkaline liquid. This increase is explained by the dissolution of orthopyroxene and the precipitation of olivine and minor clinopyroxene. The dissolution of orthopyroxene is in line with a decrease in incompatible traceelement contents in the reacted melts. Pilet et al. (2008) indicated that the compositional differences between the initial nephelinitic melt and the melt produced by reaction are broadly similar to the major- and trace-element variations observed in nephelinites and basanites through alkali basalts and tholeiites. This interpretation suggests that no additional heat is required to explain the chemical continuum of alkaline rocks, and variable melt-rock ratios alone are sufficient to produce this trend. The interpretation of tholeiitic magma as a product of a reaction is valid only for volcanoes showing this continuum and where the tholeiites show similar trace-element patterns and ratios as low-SiO ${ }_{2}$ lavas. The case of Hawaii is clearly excluded because trace-element patterns of tholeiitic lavas produced during the main shield stage are significantly different from the post-shield and rejuvenated stage alkaline rocks.

In summary, all current hypotheses for the origin of alkaline lavas suggest low potential temperatures. The formation of intraplate volcanoes by the eruption of alkaline lavas ranging from nephelinite to alkali basalt and tholeiite is inconsistent with the presence of thermal anomalies at depth. This suggests that any model favoring hot thermal plumes to produce volcanoes dominated by alkaline lavas is unrealistic.

\section{CONCLUDING REMARKS}

Alkaline lavas observed worldwide, in particular the low-silica ones, are characterized by mainly similar major- and trace-element 
compositions, but with variable isotopic signatures. Many models have been proposed for the origin of these rocks, but many fail to explain simultaneously the petrological and geochemical constraints associated with their formation. First, the source of these rocks needs to be more enriched, in term of incompatible trace elements, than the primitive mantle. Second, the source needs to produce silica-undersaturated rocks like nephelinite or basanite characterized by mostly constant alkali and $\mathrm{Al}_{2} \mathrm{O}_{3} / \mathrm{TiO}_{2}$ ratios.

High-pressure experiments and thermodynamic constraints indicate that the melting of pyroxenites derived from recycled oceanic crust is unable to explain the major- and trace-element contents of alkaline magmas. Two hypotheses have been suggested involving these recycled lithologies, which are commonly assumed to be the major carrier of enriched isotopic signatures. First, oceanic crust could be digested by peridotitic mantle to produce metasomatized peridotite, which could then melt in the presence of $\mathrm{CO}_{2}$ and produce alkaline magmas. Second, meltperidotite reaction in the presence of $\mathrm{CO}_{2}$ could modify the initial composition of melt derived from recycled oceanic crust before these melts reach the surface. Nevertheless, these two models require specific conditions (amount of recycled of crust and $\mathrm{CO}_{2}$ present in the asthenospheric source, degree of partial melting at which recycled lithologies melt) to explain the trace-element signature of alkaline rocks observed worldwide.

The alternative suggests a metasomatized lithosphere model. In this model, the trace-element pattern of alkaline lavas is explained by the petrological process that controls the formation of the metasomatic veins (Pilet et al., 2011). The isotopic variability observed in these rocks is related to the heterogeneous nature of the underlying asthenospheric mantle that creates the melt that metasomatizes the lithosphere.

One important aspect of this model is that it provides a link between the $\mathrm{Na}$ - and $\mathrm{K}$-alkaline lavas. If $\mathrm{Na}$-alkaline lavas are the dominant type of rocks in oceanic settings (with some exceptions such as the petit-spot lavas and some unusual K-rich rocks in the Line Islands seamounts, central Pacific Ocean; Natland, 1976; Hirano et al., 2006; Buchs et al., 2013), continental intraplate volcanoes show more variable composition including $\mathrm{Na}$ - and $\mathrm{K}$-alkaline lavas. The formation of variable alkaline lavas in continental settings has been interpreted as indicating variation in the hydrous phases (amphibole versus mica) present in metasomatized lithospheric sources (Lloyd and Bailey, 1975). Lloyd and Bailey (1975) postulated that the change in hydrous phases is controlled by the stability of the hydrous phases as a function of the lithosphere thickness. This hypothesis is supported by more recent works that indicate that amphibole stability is restricted to pressure less than 2.83.0 $\mathrm{GPa}$, while phlogopite remains stable to $8 \mathrm{GPa}$, i.e., down to the base of thick continental lithosphere (Rapp, 1995; Harlow and Davies, 2004).

The vein-plus-wall-rock melting mechanism proposed by Foley (1992) to explain the origin of potassic alkaline magmas shares many similarities with the model developed by Pilet et al. (2004, 2008) for Na-alkaline lavas. The difference is the mineralogical composition of the metasomatic network (phlogopite- versus amphibole-rich veins). A potential difference between the generation of alkaline magmas in continental versus oceanic settings is the timing of the metasomatic enrichment of the lithosphere. This enrichment could be decoupled, in continental settings, from the process that melts the metasomatized lithosphere. An example illustrating this potential difference is the case of ultrapotassic magmas observed in Serbia (Prelević et al., 2005). The formation of lamproite and kamafugite in Serbia is explained by the melting of a heterogeneous mantle source consisting of metasomatic phlogopite-rich veins that are out of isotopic equilibrium with the peridotite wall rock (Prelević et al., 2005). The geochemistry of the Serbian ultrapotassic rocks suggests that the metasomatic enrichment of the lithosphere was related to Mesozoic subduction events while the melting of this heterogenous source during the Tertiary is related with extensional episodes linked to regional tectonic processes (Prelević et al., 2005).

A decoupling between the process that metasomatized the lithosphere and the process that remobilized this lithosphere to produce $\mathrm{K}$ - and Na-alkaline magmas in continental settings is documented for various localities (e.g., Foley, 1992; Prelević et al., 2005, 2008, 2010; Becker and Le Roex, 2006; Ma et al., 2011; Rooney et al., 2014). Nevertheless, other studies support a mostly continuous process to explain the formation of intracontinental alkaline basalt (e.g., Pilet et al., 2004; Mayer et al., 2013). Even some aspects of the model could vary from place to place. The metasomatized lithosphere model provides an explanation for both types of alkaline magmatism. On the other hand, models which suggest the formation of alkaline basalt by melting recycled $\mathrm{CO}_{2}$-rich lithologies in the asthenosphere are unable to explain the formation of potassic magmas and therefore treat separately the mechanisms responsible for the origin of $\mathrm{Na}$ - versus K-alkaline magmas.

Hot mantle plumes are frequently proposed to explain the formation of intraplate islands or intracontinental volcanoes (e.g., Courtillot et al., 2003). However, the thermal implications of the different models for the origin of alkaline magmas all point to low $T_{\mathrm{p}}$. Higher temperatures will potentially exclude the formation of alkaline rocks characterized by high incompatible traceelement contents, first by increasing the degree of partial melting of fertile lithologies from the convecting mantle, and second by allowing the enclosing depleted MORB mantle to melt. This melting will produce tholeiitic magmas which will dilute any low-degree melts from the fertile components.

The metasomatized lithosphere model opens new perspectives to explain the formation of alkaline rocks by different tectonic processes. All processes able to create low-degree melts at the base of the lithosphere (e.g., tectonic extension, small-scale convection, mantle flow, extraction of melts already present in the low-velocity zone) could generate, after percolation and differentiation of these melts across the lithosphere, amphibole-bearing veins suitable for producing, by melting, the low-Si alkaline lavas observed in intraplate volcanoes. 


\section{ACKNOWLEDGMENTS}

I thank Gillian R. Foulger and Michele Lustrino for their fantastic editing work and their numerous comments that helped to improve the manuscript. I also thank Dejan Prelević and Stefan Jung for their constructive reviews. This work has benefited from various discussions with Othmar Müntener, Michael B. Baker, and Edward M. Stolper. I dedicate this article to Don Anderson and Mike O'Hara, who always encouraged us to "think outside the box". This work was supported by the Swiss National Science Foundation (grant 200021_140494).

\section{REFERENCES CITED}

Adam, J., and Green, T., 2011, Trace element partitioning between mica- and amphibole-bearing garnet lherzolite and hydrous basanitic melt: 2 . Tasmanian Cainozoic basalts and the origins of intraplate basaltic magmas: Contributions to Mineralogy and Petrology, v. 161, p. 883-899, doi:10.1007/s00410-010-0570-7.

Allègre, C.J., 1982, Chemical geodynamics: Tectonophysics, v. 81, p. 109-132, doi:10.1016/0040-1951(82)90125-1.

Anderson, D.L., 2011, Hawaii, boundary layers and ambient mantleGeophysical Constraints: Journal of Petrology, v. 52, p. 1547-1577, doi:10.1093/petrology/egq068.

Anderson, D.L., and Natland, J.H., 2014, Mantle updrafts and mechanisms of oceanic volcanism: Proceedings of the National Academy of Sciences of the United States of America, v. 111, p. E4298-E4304, doi:10.1073/ pnas.1410229111.

Arndt, N.T., and Goldstein, S.L., 1989, An open boundary between lower continental crust and mantle: Its role in crust formation and crustal recycling: Tectonophysics, v. 161, p. 201-212, doi:10.1016/0040-1951(89)90154-6.

Asimow, P.D., Hirschmann, M.M., and Stolper, E.M., 2001, Calculation of peridotite partial melting from thermodynamic models of minerals and melts, IV. Adiabatic decompression and the composition and mean properties of mid-ocean-ridge basalts: Journal of Petrology, v. 42, p. 963-998, doi:10.1093/petrology/42.5.963.

Asimow, P.D., Dixon, J.E., and Langmuir, C.H., 2004, A hydrous melting and fractionation model for mid-ocean-ridge basalts: Application to the MidAtlantic Ridge near the Azores: Geochemistry Geophysics Geosystems, v. 5, Q01E16, doi:10.1029/2003GC000568.

Baker, M.B., Lesher, C.E., and Stolper, E.M., 2008, Predicting solidus temperatures and modes of mantle peridotites: Geochimica et Cosmochimica Acta, v. 72, p. A45.

Becker, M., and Le Roex, A.P., 2006, Geochemistry of South African on- and off-craton, Group I and Group II kimberlites: Petrogenesis and source region evolution: Journal of Petrology, v. 47, p. 673-703, doi:10.1093/ petrology/egi089.

Bodinier, J.L., Fabries, J., Lorand, J.P., Dostal, J., and Dupuy, C., 1987, Geochemistry of amphibole pyroxenite veins from the Lherz and Freychinede ultramafic bodies (Ariege, French Pyrenees): Bulletin de Mineralogie, v. 110, p. $345-358$.

Bodinier, J.L., Garrido, C.J., Chanefo, I., Bruguier, O., and Gervilla, F., 2008, Origin of pyroxenite-peridotite veined mantle by refertilization reactions: Evidence from the Ronda peridotite (southern Spain): Journal of Petrology, v. 49, p. 999-1025, doi:10.1093/petrology/egn014.

Brey, G., and Green, D.H., 1975, Role of $\mathrm{CO}_{2}$ in genesis of olivine melilite: Contributions to Mineralogy and Petrology, v. 49, p. 93-103, doi:10.1007/ BF00373853.

Brey, G., and Green, D.H., 1977, Systematic study of liquidus phase relations in olivine melilitite $+\mathrm{H}_{2} \mathrm{O}+\mathrm{CO}_{2}$ at high pressures and petrogenesis of an olivine melilitite magma: Contributions to Mineralogy and Petrology, v. 61, p. 141-162, doi:10.1007/BF00374364.

Buchs, D.M., Pilet, S., Baumgartner, P.O., Cosca, M., Flores, K.E., and Bandini, A.N., 2013, Low-volume intraplate volcanism in the Early/Middle Jurassic Pacific basin documented by accreted sequences in Costa Rica: Geochemistry Geophysics Geosystems, v. 14, p. 1552-1568, doi:10.1002/ ggge.20084.
Caroff, M., Maury, R.C., Guille, G., and Cotten, J., 1997, Partial melting below Tubuai (Austral Islands, French Polynesia): Contributions to Mineralogy and Petrology, v. 127, p. 369-382, doi:10.1007/s004100050286.

Chase, C.G., 1981, Oceanic island Pb: Two-stage histories and mantle evolution: Earth and Planetary Science Letters, v. 52, p. 277-284, doi:10.1016/0012 $-821 \mathrm{X}(81) 90182-5$.

Chauvel, C., Hofmann, A.W., and Vidal, P., 1992, HIMU-EM: The FrenchPolynesian connection: Earth and Planetary Science Letters, v. 110, p. 99-119, doi:10.1016/0012-821X(92)90042-T.

Class, C., and Goldstein, S.L., 1997; Plume-lithosphere interactions in the ocean basins: Constraints from the source mineralogy: Earth and Planetary Science Letters, v. 150, p. 245-260, doi:10.1016/0012-821X(97)00089-7.

Courtillot, V., Davaille, A., Besse, J., and Stock, J., 2003, Three distinct types of hotspots in the Earth's mantle: Earth and Planetary Science Letters, v. 205, p. 295-308, doi:10.1016/S0012-821X(02)01048-8.

Dasgupta, R., and Hirschmann, M.M., 2006, Melting in the Earth's deep upper mantle caused by carbon dioxide: Nature, v. 440, p. 659-662, doi:10.1038/nature04612.

Dasgupta, R., and Hirschmann, M.M., 2007, Partial melting experiments of peridotite $+\mathrm{CO}_{2}$ at $3 \mathrm{GPa}$ and genesis of alkalic ocean island basalts: Journal of Petrology, v. 48, p. 2093-2124, doi:10.1093/petrology/egm053.

Dasgupta, R., Hirschmann, M.M., and Withers, A.C., 2004, Deep global cycling of carbon constrained by the solidus of anhydrous, carbonated eclogite under upper mantle conditions: Earth and Planetary Science Letters, v. 227, p. 73-85, doi:10.1016/j.eps1.2004.08.004.

Dasgupta, R., Hirschmann, M.M., and Stalker, K., 2006, Immiscible transition from carbonate-rich to silicate-rich melts in the $3 \mathrm{GPa}$ melting interval of eclogite plus $\mathrm{CO}_{2}$ and genesis of silica-undersaturated ocean island lavas: Journal of Petrology, v. 47, p. 647-671, doi:10.1093/ petrology/egi088.

Dasgupta, R., Hirschmann, M.M., and Smith, N.D., 2007, Water follows carbon: $\mathrm{CO}_{2}$ incites deep silicate melting and dehydration beneath mid-ocean ridges: Geology, v. 35, p. 135-138, doi:10.1130/G22856A.1.

Davis, F.A., and Hirschmann, M.M., 2013, The effects of $\mathrm{K}_{2} \mathrm{O}$ on the compositions of near-solidus melts of garnet peridotite at $3 \mathrm{GPa}$ and the origin of basalts from enriched mantle: Contributions to Mineralogy and Petrology, v. 166, p. 1029-1046, doi:10.1007/s00410-013-0907-0.

Davis, F.A., Hirschmann, M.M., and Humayun, M., 2011, The composition of the incipient partial melt of garnet peridotite at $3 \mathrm{GPa}$ and the origin of OIB: Earth and Planetary Science Letters, v. 308, p. 380-390, doi:10.1016/j.eps1.2011.06.008.

Eggler, D.H., and Holloway, J.R., 1977, Partial melting of peridotite in the presence of $\mathrm{H}_{2} \mathrm{O}$ and $\mathrm{CO}_{2}$ : Principles and review, in Dick, H.J.B, ed., Magma Genesis: Oregon Department of Geology and Mineral Industries Bulletin 96, p. $15-36$.

Ellam, R.M., 1992, Lithospheric thickness as a control on basalt geochemistry: Geology, v. 20, p. 153-156, doi:10.1130/0091-7613(1992)020<0153 :LTAACO $>2.3 . \mathrm{CO} ; 2$.

Elliott, T., Thomas, A., Jeffcoate, A., and Niu, Y.L., 2006, Lithium isotope evidence for subduction-enriched mantle in the source of mid-ocean-ridge basalts: Nature, v. 443, p. 565-568, doi:10.1038/nature05144.

Falloon, T.J., and Green, D.H., 1989, The solidus of carbonated, fertile peridotite: Earth and Planetary Science Letters, v. 94, p. 364-370, doi:10.1016/0012-821X(89)90153-2.

Foley, S.F., 1992, Vein-plus-wall-rock melting mechanisms in the lithosphere and the origin of potassic alkaline magmas: Lithos, v. 28, p. $435-453$, doi:10.1016/0024-4937(92)90018-T.

Foley, S.F., Yaxley, G.M., Rosenthal, A., Buhre, S., Kiseeva, E.S., Rapp, R.P., and Jacob, D.E., 2009, The composition of near-solidus melts of peridotite in the presence of $\mathrm{CO}_{2}$ and $\mathrm{H}_{2} \mathrm{O}$ between 40 and 60 kbar: Lithos, v. 112, p. 274-283, doi:10.1016/j.lithos.2009.03.020.

Frey, F.A., Wise, W.S., Garcia, M.O., West, H., Kwon, S.T., and Kennedy, A., 1990, Evolution of Mauna Kea Volcano, Hawaii: Petrologic and geochemical constraints on postshield volcanism: Journal of Geophysical Research, v. 95, p. 1271-1300, doi:10.1029/JB095iB02p01271.

Gast, P.W., 1968, Trace element fractionation and origin of tholeiitic and alkaline magma types: Geochimica et Cosmochimica Acta, v. 32, p. 10571086, doi:10.1016/0016-7037(68)90108-7.

Gerbode, C., and Dasgupta, R., 2010, Carbonate-fluxed melting of MORB-like pyroxenite at $2.9 \mathrm{GPa}$ and genesis of HIMU ocean island basalts: Journal of Petrology, v. 51, p. 2067-2088, doi:10.1093/petrology/egq049. 
Green, D.H., 1973, Conditions of melting of basanite magma from garnet peridotite: Earth and Planetary Science Letters, v. 17, p. 456-465, doi:10.1016/0012-821X(73)90214-8.

Green, D.H., and Ringwood, A.E., 1967, The genesis of basaltic magmas: Contributions to Mineralogy and Petrology, v. 15, p. 103-190, doi:10.1007/ BF00372052.

Green, D.H., Falloon, T.J., Eggins, S.M., and Yaxley, G.M., 2001, Primary magmas and mantle temperatures: European Journal of Mineralogy, v. 13, p. 437-451, doi:10.1127/0935-1221/2001/0013-0437.

Green, T.H., Green, D.H., and Ringwood, A.E., 1967, Origin of high-alumina basalts and their relationships to quartz tholeiites and alkali basalts: Earth and Planetary Science Letters, v. 2, p. 41-51, doi:10.1016/0012821X(67)90171-9.

Gudfinnsson, G.H., and Presnall, D.C., 2005, Continuous gradations among primary carbonatitic, kimberlitic, melilititic, basaltic, picritic, and komatiitic melts in equilibrium with garnet lherzolite at 3-8 GPa: Journal of Petrology, v. 46, p. 1645-1659, doi:10.1093/petrology/egi029.

Halliday, A.N., Lee, D.C., Tommasini, S., Davies, G.R., Paslick, C.R., Fitton, J.G., and James, D.E., 1995, Incompatible trace elements in OIB and MORB and source enrichment in the sub-oceanic mantle: Earth and Planetary Science Letters, v. 133, p. 379-395, doi:10.1016/0012 $-821 \mathrm{X}(95) 00097-\mathrm{V}$.

Hammouda, T., 2003, High-pressure melting of carbonated eclogite and experimental constraints on carbon recycling and storage in the mantle: Earth and Planetary Science Letters, v. 214, p. 357-368, doi:10.1016/S0012 $-821 X(03) 00361-3$.

Harlow, G.E., and Davies, R., 2004, Status report on stability of K-rich phases at mantle conditions: Lithos, v. 77, p. 647-653, doi:10.1016/j .lithos.2004.04.010

Hart, S.R., and Gaetani, G.A., 2006, Mantle Pb paradoxes: The sulfide solution: Contributions to Mineralogy and Petrology, v. 152, p. 295-308, doi:10.1007/s00410-006-0108-1.

Harte, B., Hunter, R.H., and Kinny, P.D., 1993, Melt geometry, movement and crystallization, in relation to mantle dykes, veins and metasomatism: Philosophical Transactions of the Royal Society of London, ser. A, v. 342, p. 1-21, doi:10.1098/rsta.1993.0001.

Hawkesworth, C.J., Mantovani, M.S.M., Taylor, P.N., and Palacz, Z., 1986, Evidence from the Parana of south Brazil for a continental contribution to Dupal basalts: Nature, v. 322, p. 356-359, doi:10.1038/322356a0.

Heinonen, J.S., and Luttinen, A.V., 2010, Mineral chemical evidence for extremely magnesian subalkaline melts from the Antarctic extension of the Karoo large igneous province: Mineralogy and Petrology, v. 99, p. 201-217, doi:10.1007/s00710-010-0115-9.

Herzberg, C., and Gazel, E., 2009, Petrological evidence for secular cooling in mantle plumes: Nature, v. 458, p. 619-622, doi:10.1038/ nature 07857.

Herzberg, C., and O'Hara, M.J., 1998, Phase equilibrium constraints on the origin of basalts, picrites and komatiites: Earth-Science Reviews, v. 44, p. 39-79, doi:10.1016/S0012-8252(98)00021-X.

Hirano, N., Takahashi, E., Yamamoto, J., Abe, N., Ingle, S.P., Kaneoka, I., Hirata, T., Kimura, J.-I., Ishii, T., Ogawa, Y., Machida, S., and Suyehiro, K., 2006, Volcanism in response to plate flexure: Science, v. 313, p. 1426 1428, doi:10.1126/science.1128235.

Hirose, K., 1997, Partial melt compositions of carbonated peridotite at $3 \mathrm{GPa}$ and role of $\mathrm{CO}_{2}$ in alkali-basalt magma generation: Geophysical Research Letters, v. 24, p. 2837-2840, doi:10.1029/97GL02956.

Hirose, K., and Kushiro, I., 1993, Partial melting of dry peridotites at highpressures: Determination of compositions of melts segregated from peridotite using aggregates of diamond: Earth and Planetary Science Letters, v. 114 , p. $477-489$, doi:10.1016/0012-821X(93)90077-M.

Hirschmann, M.M., 2000, Mantle solidus: Experimental constraints and the effects of peridotite composition: Geochemistry Geophysics Geosystems, v. 1, 1042, doi:10.1029/2000GC000070.

Hirschmann, M.M., and Stolper, E.M., 1996, A possible role for garnet pyroxenite in the origin of the "garnet signature" in MORB: Contributions to Mineralogy and Petrology, v. 124, p. 185-208, doi:10.1007/ s004100050184.

Hirschmann, M.M., Ghiorso, M.S., Wasylenki, L.E., Asimow, P.D., and Stolper, E.M., 1998, Calculation of peridotite partial melting from thermodynamic models of minerals and melts. I. Review of methods and comparison with experiments: Journal of Petrology, v. 39, p. 1091-1115, doi:10.1093/ petroj/39.6.1091.
Hirschmann, M.M., Kogiso, T., Baker, M.B., and Stolper, E.M., 2003, Alkalic magmas generated by partial melting of garnet pyroxenite: Geology, v. 31, p. 481-484, doi:10.1130/0091-7613(2003)031<0481:AMGBPM> 2.0.CO;2.

Hofmann, A.W., 1997, Mantle geochemistry: The message from oceanic volcanism: Nature, v. 385, p. 219-229, doi:10.1038/385219a0.

Hofmann, A.W., and White, W.M., 1982, Mantle plumes from ancient oceanic crust: Earth and Planetary Science Letters, v. 57, p. 421-436, doi:10.1016/0012-821X(82)90161-3.

Hofmann, A.W., Jochum, K.P., Seufert, M., and White, W.M., 1986, Nb and Pb in oceanic basalts: New constraints on mantle evolution: Earth and Planetary Science Letters, v. 79, p. 33-45, doi:10.1016/0012-821X(86)90038-5.

Irvine, T.N., and Baragar, W.R.A., 1971, A guide to the chemical classification of the common volcanic rocks: Canadian Journal of Earth Sciences, v. 8, p. 523-548, doi:10.1139/e71-055.

Ito, G., and Mahoney, J.J., 2005, Flow and melting of a heterogeneous mantle: 1. Method and importance to the geochemistry of ocean island and midocean-ridge basalts: Earth and Planetary Science Letters, v. 230, p. 29-46, doi:10.1016/j.epsl.2004.10.035.

Jung, S., Pfander, J.A., Brugmann, G., and Stracke, A., 2005, Sources of primitive alkaline volcanic rocks from the central European volcanic province (Rhön, Germany) inferred from Hf, Os and $\mathrm{Pb}$ isotopes: Contributions to Mineralogy and Petrology, v. 150, p. 546-559, doi:10.1007/s00410 $-005-0029-4$.

Katz, R.F., Spiegelman, M., and Langmuir, C.H., 2003, A new parameterization of hydrous mantle melting: Geochemistry Geophysics Geosystems, v. 4, 1073, doi:10.1029/2002GC000433.

Kawakatsu, H., Kumar, P., Takei, Y., Shinohara, M., Kanazawa, T., Araki, E., and Suyehiro, K., 2009, Seismic evidence for sharp lithosphereasthenosphere boundaries of oceanic plates: Science, v. 324, p. 499-502.

Keshav, S., Gudfinnsson, G.H., Sen, G., and Fei, Y.W., 2004, High-pressure melting experiments on garnet clinopyroxenite and the alkalic to tholeiitic transition in ocean-island basalts: Earth and Planetary Science Letters, v. 223, p. 365-379, doi:10.1016/j.eps1.2004.04.029.

Kessel, R., Schmidt, M.W., Ulmer, P., and Pettke, T., 2005a, Trace element signature of subduction-zone fluids, melts and supercritical liquids at 120-180 km depth: Nature, v. 437, p. 724-727, doi:10.1038/nature03971.

Kessel, R., Ulmer, P., Pettke, T., Schmidt, M.W., and Thompson, A.B., 2005b, The water-basalt system at 4 to $6 \mathrm{GPa}$ : Phase relations and second critical endpoint in a K-free eclogite at 700 to $1400^{\circ} \mathrm{C}$ : Earth and Planetary Science Letters, v. 237, p. 873-892, doi:10.1016/j.eps1.2005.06.018.

Kinzler, R.J., and Grove, T.L., 1992, Primary magmas of mid-ocean-ridge basalts 2. Applications: Journal of Geophysical Research, v. 97, p. 69076926, doi:10.1029/91JB02841.

Kiseeva, E.S., Yaxley, G.M., Hermann, J., Litasov, K.D., Rosenthal, A., and Kamenetsky, V.S., 2012, An experimental study of carbonated eclogite at 3.5-5.5 GPa-Implications for silicate and carbonate metasomatism in the cratonic mantle: Journal of Petrology, v. 53, p. 727-759, doi:10.1093/ petrology/egr078.

Kogiso, T., and Hirschmann, M.M., 2006, Partial melting experiments of bimineralic eclogite and the role of recycled mafic oceanic crust in the genesis of ocean island basalts: Earth and Planetary Science Letters, v. 249, p. 188-199, doi:10.1016/j.epsl.2006.07.016.

Kogiso, T., Hirschmann, M.M., and Frost, D.J., 2003, High-pressure partial melting of garnet pyroxenite: Possible mafic lithologies in the source of ocean island basalts: Earth and Planetary Science Letters, v. 216, p. 603617, doi:10.1016/S0012-821X(03)00538-7.

Kogiso, T., Hirschmann, M.M., and Pertermann, M., 2004, High-pressure partial melting of mafic lithologies in the mantle: Journal of Petrology, v. 45, p. 2407-2422, doi:10.1093/petrology/egh057.

Kushiro, I., 1968, Compositions of magmas formed by partial zone melting of Earth upper mantle: Journal of Geophysical Research, v. 73, p. 619-634, doi:10.1029/JB073i002p00619.

Kushiro, I., 1975, On the nature of silicate melt and its significance in magma genesis: Regularities in the shift of the liquidus boundaries involving olivine, pyroxene, and silica minerals: American Journal of Science, v. 275, p. 411-431, doi:10.2475/ajs.275.4.411.

Kushiro, I., 1996, Partial melting of a fertile mantle peridotite at high pressures: An experimental study using aggregates of diamond, in Basu, A., and Hart, S., eds., Earth Processes: Reading the Isotopic Code: American Geophysical Union Geophysical Monograph 95, p. 109-122, doi:10.1029/ GM095p0109. 
Lambart, S., Laporte, D., and Schiano, P., 2009, An experimental study of pyroxenite partial melts at 1 and $1.5 \mathrm{GPa}$ : Implications for the majorelement composition of mid-ocean-ridge basalts: Earth and Planetary Science Letters, v. 288, p. 335-347, doi:10.1016/j.epsl.2009.09.038.

Lambart, S., Laporte, D., Provost, A., and Schiano, P., 2012, Fate of pyroxenite-derived melts in the peridotitic mantle: Thermodynamic and experimental constraints: Journal of Petrology, v. 53, p. 451-476, doi:10.1093/petrology/egr068.

Lambart, S., Laporte, D., and Schiano, P., 2013, Markers of the pyroxenite contribution in the major-element compositions of oceanic basalts: Review of the experimental constraints: Lithos, v. 160, p. 14-36, doi:10.1016/j .lithos.2012.11.018.

Lloyd, F.E., and Bailey, D.K., 1975, Light element metasomatism of the continental mantle: The evidence and the consequences: Physics and Chemistry of the Earth, v. 9, p. 389-416, doi:10.1016/0079-1946(75)90030-0.

Lundstrom, C.C., Gill, J., and Williams, Q., 2000, A geochemically consistent hypothesis for MORB generation: Chemical Geology, v. 162, p. 105-126, doi:10.1016/S0009-2541(99)00122-9.

Lustrino, M., 2011, What 'anorogenic' igneous rocks can tell us about the chemical composition of the upper mantle: Case studies from the circum-Mediterranean area: Geological Magazine, v. 148, p. 304-316, doi:10.1017/S0016756810000695.

Lustrino, M., Melluso, L., and Morra, V., 2002, The transition from alkaline to tholeiitic magmas: A case study from the Orosei-Dorgali Pliocene volcanic district (NE Sardinia, Italy): Lithos, v. 63, p. 83-113, doi:10.1016/ S0024-4937(02)00113-5.

Ma, G.S.K., Malpas, J., Xenophontos, C., and Chan, G.H.N., 2011, Petrogenesis of latest Miocene-Quaternary continental intraplate volcanism along the Northern Dead Sea fault system (Al Ghab-Homs volcanic field), western Syria: Evidence for lithosphere-asthenosphere interaction: Journal of Petrology, v. 52, p. 401-430, doi:10.1093/petrology/egq085.

Mallik, A., and Dasgupta, R., 2012, Reaction between MORB-eclogite derived melts and fertile peridotite and generation of ocean island basalts: Earth and Planetary Science Letters, v. 329, p. 97-108, doi:10.1016/j. eps1.2012.02.007.

Mallik, A., and Dasgupta, R., 2013, Reactive infiltration of MORB-eclogitederived carbonated silicate melt into fertile peridotite at $3 \mathrm{GPa}$ and genesis of alkalic magmas: Journal of Petrology, v. 54, p. 2267-2300, doi:10.1093/petrology/egt047.

Mallik, A., and Dasgupta, R., 2014, Effect of variable $\mathrm{CO}_{2}$ on eclogite-derived andesite and lherzolite reaction at $3 \mathrm{GPa}$-Implications for mantle source characteristics of alkalic ocean island basalts: Geochemistry Geophysics Geosystems, v. 15, p. 1533-1557, doi:10.1002/2014GC005251.

Mayer, B., Jung, S., Romer, R.L., Stracke, A., Haase, K.M., and GarbeSchönberg, C.D., 2013, Petrogenesis of Tertiary hornblende-bearing lavas in the Rhön, Germany: Journal of Petrology, v. 54, p. 2095-2123, doi:10.1093/petrology/egt042.

McDonough, W.F., and Sun, S.S., 1995, The composition of the Earth: Chemical Geology, v. 120, p. 223-253, doi:10.1016/0009-2541(94)00140-4.

McKenzie, D., and Onions, R.K., 1995, The source regions of ocean island basalts: Journal of Petrology, v. 36, p. 133-159, doi:10.1093/ petrology/36.1.133.

Meibom, A., and Anderson, D.L., 2004, The statistical upper mantle assemblage: Earth and Planetary Science Letters, v. 217, p. 123-139, doi:10.1016/S0012-821X(03)00573-9.

Mitchell, R.H., ed., 1996, Undersaturated Alkaline Rocks: Mineralogy, Petrogenesis, and Economic Potential: Mineralogical Association of Canada Short Course 24, $312 \mathrm{p}$.

Müntener, O., Manatschal, G., Desmurs, L., and Pettke, T., 2010, Plagioclase peridotites in ocean-continent transitions: Refertilized mantle domains generated by melt stagnation in the shallow mantle lithosphere: Journal of Petrology, v. 51, p. 255-294, doi:10.1093/petrology/egp087.

Natland, J.H., 1976, Petrology of volcanic rocks dredged from seamounts in the Line Islands, in Initial Reports of the Deep Sea Drilling Project, Volume 33: College Station, Texas A\&M University, p. 749-777, doi:10.2973/ dsdp.proc.33.126.1976.

Nekvasil, H., Dondolini, A., Horn, J., Filiberto, J., Long, H., and Lindsley, D.H., 2004, The origin and evolution of silica-saturated alkalic suites: An experimental study: Journal of Petrology, v. 45, p. 693-721, doi:10.1093/ petrology/egg 103 .

Nielson, J.E., and Noller, J.S., 1987, Processes of mantle metasomatism: Constraints from observations of composite peridotite xenoliths, in Morris,
E.M., and Pasteris, J.D., eds., Mantle Metasomatism and Alkaline Magmatism: Geological Society of America Special Paper 215, p. 61-76, doi:10.1130/SPE215-p61.

Nielson, J.E., and Wilshire, H.G., 1993, Magma transport and metasomatism in the mantle: A critical review of current geochemical models: The American Mineralogist, v. 78, p. 1117-1134.

Niu, Y.L., and O'Hara, M.J., 2003, Origin of ocean island basalts: A new perspective from petrology, geochemistry, and mineral physics considerations: Journal of Geophysical Research, v. 108, 2209, doi:10.1029/2002JB002048.

Niu, Y.L., Wilson, M., Humphreys, E.R., and O'Hara, M.J., 2011, The origin of intra-plate ocean island basalts (OIB): The lid effect and its geodynamic implications: Journal of Petrology, v. 52, p. 1443-1468, doi:10.1093/ petrology/egr030

Panter, K.S., Blusztajn, J., Hart, S.R., Kyle, P.R., Esser, R., and McIntosh, W.C., 2006, The origin of HIMU in the SW Pacific: Evidence from intraplate volcanism in southern New Zealand and subantarctic islands: Journal of Petrology, v. 47, p. 1673-1704, doi:10.1093/petrology/eg1024.

Pertermann, M., and Hirschmann, M.M., 2003a, Anhydrous partial melting experiments on MORB-like eclogite: Phase relations, phase compositions and mineral-melt partitioning of major elements at 2-3 GPa: Journal of Petrology, v. 44, p. 2173-2201, doi:10.1093/petrology/egg074.

Pertermann, M., and Hirschmann, M.M., 2003b, Partial melting experiments on a MORB-like pyroxenite between 2 and $3 \mathrm{GPa}$ : Constraints on the presence of pyroxenite in basalt source regions from solidus location and melting rate: Journal of Geophysical Research, v. 108, B02201, doi:10.1029/2003JB002566.

Phipps Morgan, J., 2001, Thermodynamics of pressure release melting of a veined plum pudding mantle: Geochemistry Geophysics Geosystems, v. 2, 1001, doi:10.1029/2000GC000049.

Pilet, S., Hernandez, J., Bussy, F., and Sylvester, P.J., 2004, Short-term metasomatic control of $\mathrm{Nb} / \mathrm{Th}$ ratios in the mantle sources of intraplate basalts: Geology, v. 32, p. 113-116, doi:10.1130/G19953.1.

Pilet, S., Hernandez, J., Sylvester, P., and Poujol, M., 2005, The metasomatic alternative for ocean island basalt chemical heterogeneity: Earth and Planetary Science Letters, v. 236, p. 148-166, doi:10.1016/j .eps1.2005.05.004.

Pilet, S., Baker, M.B., and Stolper, E.M., 2008, Metasomatized lithosphere and the origin of alkaline lavas: Science, v. 320, p. 916-919, doi:10.1126/ science. 1156563.

Pilet, S., Ulmer, P., and Villiger, S., 2010, Liquid line of descent of a basanitic liquid at $1.5 \mathrm{GPa}$ : Constraints on the formation of metasomatic veins: Contributions to Mineralogy and Petrology, v. 159, p. 621-643, doi:10.1007/s00410-009-0445-y.

Pilet, S., Baker, M.B., Müntener, O., and Stolper, E.M., 2011, Monte Carlo simulations of metasomatic enrichment in the lithosphere and implications for the source of alkaline basalts: Journal of Petrology, v. 52, p. 14151442, doi:10.1093/petrology/egr007.

Prelević, D., Foley, S.F., Romer, R.L., Cvetković, V., and Downes, H., 2005, Tertiary ultrapotassic volcanism in Serbia: Constraints on petrogenesis and mantle source characteristics: Journal of Petrology, v. 46, p. 1443 1487, doi:10.1093/petrology/egi022.

Prelević, D., Foley, S.F., Romer, R., and Conticelli, S., 2008, Mediterranean Tertiary lamproites derived from multiple source components in postcollisional geodynamics: Geochimica et Cosmochimica Acta, v. 72, p. 2125 2156, doi:10.1016/j.gca.2008.01.029.

Prelević, D., Akal, C., Romer, R.L., and Foley, S.F., 2010, Lamproites as indicators of accretion and/or shallow subduction in the assembly of southwestern Anatolia, Turkey: Terra Nova, v. 22, p. 443-452, doi:10.1111/ j.1365-3121.2010.00963.x.

Presnall, D.C., and Gudfinnsson, G.H., 2011, Oceanic volcanism from the low-velocity zone-without mantle plumes: Journal of Petrology, v. 52, p. 1533-1546, doi:10.1093/petrology/egq093.

Prytulak, J., and Elliott, T., 2007, $\mathrm{TiO}_{2}$ enrichment in ocean island basalts: Earth and Planetary Science Letters, v. 263, p. 388-403, doi:10.1016/j .eps1.2007.09.015.

Putirka, K.D., 2005, Mantle potential temperatures at Hawaii, Iceland, and the mid-ocean ridge system, as inferred from olivine phenocrysts: Evidence for thermally driven mantle plumes: Geochemistry Geophysics Geosystems, v. 6, Q05L08, doi:10.1029/2005GC000915.

Putirka, K.D., Perfit, M., Ryerson, F.J., and Jackson, M.G., 2007, Ambient and excess mantle temperatures, olivine thermometry, and active vs. 
passive upwelling: Chemical Geology, v. 241, p. 177-206, doi:10.1016/j .chemgeo.2007.01.014.

Rapp, R.P., 1995, Amphibole-out phase boundary in partially melted metabasalt, its control over liquid fraction and composition, and source permeability: Journal of Geophysical Research, v. 100, p. 15,601-15,610, doi:10.1029/95JB00913.

Rooney, T.O., Nelson, W.R., Dosso, L., Furman, T., and Hanan, B., 2014, The role of continental lithosphere metasomes in the production of HIMU-like magmatism on the northeast African and Arabian plates: Geology, v. 42, p. 419-422, doi:10.1130/G35216.1.

Salters, V.J.M., and Stracke, A., 2004, Composition of the depleted mantle: Geochemistry Geophysics Geosystems, v. 5, Q05B07, doi:10.1029/2003GC000597.

Schmincke, H.-U., 2004, Volcanism: Heidelberg, Springer-Verlag, 324 p., doi:10.1007/978-3-642-18952-4.

Sims, K.W.W., and DePaolo, D.J., 1997, Inferences about mantle magma sources from incompatible element concentration ratios in oceanic basalts: Geochimica et Cosmochimica Acta, v. 61, p. 765-784, doi:10.1016/S0016 -7037(96)00372-9.

Sobolev, A.V., Hofmann, A.W., Sobolev, S.V., and Nikogosian, I.K., 2005, An olivine-free mantle source of Hawaiian shield basalts: Nature, v. 434, p. 590-597, doi:10.1038/nature03411.

Sobolev, A.V., and 19 others, 2007, The amount of recycled crust in sources of mantle-derived melts: Science, v. 316, p. 412-417, doi:10.1126/science .1138113.

Spandler, C., Yaxley, G., Green, D.H., and Rosenthal, A., 2008, Phase relations and melting of anhydrous K-bearing eclogite from 1200 to $1600{ }^{\circ} \mathrm{C}$ and 3 to $5 \mathrm{GPa}$ : Journal of Petrology, v. 49, p. 771-795, doi:10.1093/petrology/ egm039.

Stolper, E.M., and Asimow, P.D., 2007, Insights into mantle melting from graphical analysis of one-component systems: American Journal of Science, v. 307, p. 1051-1139, doi:10.2475/08.2007.01.

Stracke, A., 2012, Earth's heterogeneous mantle: A product of convectiondriven interaction between crust and mantle: Chemical Geology, v. 330, p. 274-299, doi:10.1016/j.chemgeo.2012.08.007.

Stracke, A., Bizimis, M., and Salters, V.J.M., 2003, Recycling oceanic crust: Quantitative constraints: Geochemistry Geophysics Geosystems, v. 4, 8003, doi:10.1029/2001GC000223.

Takahashi, E., Nakajima, K., and Wright, T.L., 1998, Origin of the Columbia River basalts: Melting model of a heterogeneous plume head: Earth and Planetary Science Letters, v. 162, p. 63-80, doi:10.1016/S0012 $-821 X(98) 00157-5$.

Tiepolo, M., Vannucci, R., Bottazzi, P., Oberti, R., Zanetti, A., and Foley, S.F., 2000, Partitioning of rare earth elements, Y, Th, U, and Pb between pargasite, kaersutite, and basanite to trachyte melts: Implications for percolated and veined mantle: Geochemistry Geophysics Geosystems, v. 1, 1039, doi:10.1029/2000GC000064.

Van der Wal, D., and Bodinier, J.L., 1996, Origin of the recrystallisation front in the Ronda peridotite by km-scale pervasive porous melt flow: Contributions to Mineralogy and Petrology, v. 122, p. 387-405, doi:10.1007/ s004100050135.

Wallace, M.E., and Green, D.H., 1988, An experimental determination of primary carbonatitic magma composition: Nature, v. 335, p. 343-346, doi: $10.1038 / 335343 \mathrm{a} 0$.
Walter, M.J., 1998, Melting of garnet peridotite and the origin of komatiite and depleted lithosphere: Journal of Petrology, v. 39, p. 29-60, doi:10.1093/ petroj/39.1.29.

Wasylenki, L.E., Baker, M.B., Kent, A.J.R., and Stolper, E.M., 2003, Nearsolidus melting of the shallow upper mantle: Partial melting experiments on depleted peridotite: Journal of Petrology, v. 44, p. 1163-1191, doi:10.1093/petrology/44.7.1163.

Weaver, B.L., 1991, The origin of ocean island basalt end-member compositions: Trace-element and isotopic constraints: Earth and Planetary Science Letters, v. 104, p. 381-397, doi:10.1016/0012-821X(91)90217-6.

Wendlandt, R.F., and Mysen, B.O., 1980, Melting phase relations of natural peridotite $+\mathrm{CO}_{2}$ as a function of degree of partial melting at 15 and 30 kbar: The American Mineralogist, v. 65, p. 37-44.

Willbold, M., and Stracke, A., 2006, Trace element composition of mantle end-members: Implications for recycling of oceanic and upper and lower continental crust: Geochemistry Geophysics Geosystems, v. 7, Q04004, doi:10.1029/2005GC001005.

Willbold, M., and Stracke, A., 2010, Formation of enriched mantle components by recycling of upper and lower continental crust: Chemical Geology, v. 276, p. 188-197, doi:10.1016/j.chemgeo.2010.06.005.

Wilshire, H.G., 1987, A model of mantle metasomatism, in Morris, E.M., and Pasteris, J.D., eds., Mantle Metasomatism and Alkaline Magmatism: Geological Society of America Special Paper 215, p. 47-60, doi:10.1130/ SPE215-p47.

Wilson, M., Downes, H., and Cebria, J.M., 1995, Contrasting fractionation trends in coexisting continental alkaline magmas series: Cantal, Massif Central, France: Journal of Petrology, v. 36, p. 1729-1753.

Workman, R.K., and Hart, S.R., 2005, Major and trace element composition of the depleted MORB mantle (DMM): Earth and Planetary Science Letters, v. 231, p. 53-72, doi:10.1016/j.eps1.2004.12.005.

Wyllie, P.J., 1977, Mantle fluid compositions buffered by carbonates in peridotite- $\mathrm{CO}_{2}-\mathrm{H}_{2} \mathrm{O}$ : The Journal of Geology, v. 85, p. 187-207, doi:10.1086/628285.

Wyllie, P.J., and Huang, W.-L., 1976, Carbonation and melting reactions in the system $\mathrm{CaO}-\mathrm{MgO}-\mathrm{SiO}_{2}-\mathrm{CO}_{2}$ at mantle pressures with geophysical and petrological applications: Contributions to Mineralogy and Petrology, v. 54, p. 79-107, doi:10.1007/BF00372117.

Yaxley, G.M., and Brey, G.P., 2004, Phase relations of carbonate-bearing eclogite assemblages from 2.5 to $5.5 \mathrm{GPa}$ : Implications for petrogenesis of carbonatites: Contributions to Mineralogy and Petrology, v. 146, p. 606-619, doi:10.1007/s00410-003-0517-3.

Yaxley, G.M., and Green, D.H., 1998, Reactions between eclogite and peridotite: Mantle refertilisation by subduction of oceanic crust: Schweizerische Mineralogische und Petrographische Mitteilungen, v. 78, p. 243-255.

Yaxley, G.M., and Sobolev, A.V., 2007, High-pressure partial melting of gabbro and its role in the Hawaiian magma source: Contributions to Mineralogy and Petrology, v. 154, p. 371-383, doi:10.1007/s00410-007-0198-4.

Zindler, A., and Hart, S., 1986, Chemical geodynamics: Annual Review of Earth and Planetary Sciences, v. 14, p. 493-571, doi:10.1146/annurev ea.14.050186.002425.

Manuscript Accepted by the Society 2 February 2015

Manuscript Published Online 28 August 2015 


\title{
Geological Society of America Special Papers
}

\section{Generation of low-silica alkaline lavas: Petrological constraints, models, and thermal implications}

\author{
Sébastien Pilet
}

Geological Society of America Special Papers 2015;514; 281-304 , originally published onlineAugust 28, 2015

doi:10.1130/2015.2514(17)

\section{E-mail alerting services click www.gsapubs.org/cgi/alerts to receive free e-mail alerts when new articles cite this article \\ Subscribe \\ click www.gsapubs.org/subscriptions to subscribe to Geological Society of America Special Papers \\ Permission request \\ click www.geosociety.org/pubs/copyrt.htm\#gsa to contact GSA.}

Copyright not claimed on content prepared wholly by U.S. government employees within scope of their employment. Individual scientists are hereby granted permission, without fees or further requests to GSA, to use a single figure, a single table, and/or a brief paragraph of text in subsequent works and to make unlimited copies of items in GSA's journals for noncommercial use in classrooms to further education and science. This file may not be posted to any Web site, but authors may post the abstracts only of their articles on their own or their organization's Web site providing the posting includes a reference to the article's full citation. GSA provides this and other forums for the presentation of diverse opinions and positions by scientists worldwide, regardless of their race, citizenship, gender, religion, or political viewpoint. Opinions presented in this publication do not reflect official positions of the Society.

Notes

C 2015 Geological Society of America

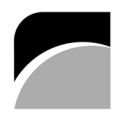

THE GEOLOGICAL SOCIETY OF AMERICA 